\title{
Value and Quality in the Dialectics between Human and Urban Capital of the City Networks on the Land District Scale
}

\author{
Ludovica Nasca $^{1}$, Salvatore Giuffrida ${ }^{2}$ (D) and Maria Rosa Trovato ${ }^{2, *(D)}$ \\ 1 Department of Architecture Design and Urban Planning, University of Sassari, Piazza Duomo 6, \\ 07041 Alghero, Italy; ludovicanasca@yahoo.it \\ 2 Department of Civil Engineering and Architecture, University of Catania, Via Santa Sofia 23, \\ 95124 Catania, Italy; salvatore.giuffrida@unict.it \\ * Correspondence: mrtrovato@dica.unict.it
}

check for updates

Citation: Nasca, L.; Giuffrida, S.; Trovato, M.R. Value and Quality in the Dialectics between Human and Urban Capital of the City Networks on the Land District Scale. Land 2022, 11, 34. https://doi.org/10.3390/ land11010034

Academic Editor:

Anna Winiarczyk-Raźniak

Received: 1 November 2021

Accepted: 16 December 2021

Published: 26 December 2021

Publisher's Note: MDPI stays neutral with regard to jurisdictional claims in published maps and institutional affiliations.

Copyright: (C) 2021 by the authors. Licensee MDPI, Basel, Switzerland. This article is an open access article distributed under the terms and conditions of the Creative Commons Attribution (CC BY) license (https:// creativecommons.org/licenses/by/ $4.0 /)$.
Abstract: This contribution proposes an inter-scalar and multi-polar analysis evaluation model of the territory of the Enna district, aimed at providing a robust axiological representation of the salient aspects of the general issue of internal areas, and therefore of the set of criticalities affecting them from the perspective of the human and urban capital they express. In the prospect of investigating the relations between urban and life quality—corresponding to the "city effect" —in the territorial context of each of the 20 municipalities of the Enna district, a hierarchical descriptive-valuation model was created, which coordinates a relevant amount of information units (data) and the corresponding attributes, indicators and indices that have been turned in aggregate value judgments attributed to each administrative land unit, from the perspectives of the criteria referred to as the main forms of the territorial capital. This is a multi-dimensional valuation model based on the Multi-Attribute Value Theory. Each survey and processing is mapped with different levels of detail at the scale of municipalities, census sections and cadastral land units. The outcome of this complex process of analysis and assessment provides multiple comparisons, revealing unexpected and sometimes counter-intuitive aspects in several municipalities, some of which are characterised by innovative prospects and opportunities for redevelopment of their historic centers. Correlations between information units at the different levels of the dendrogram have also indicated interesting trends and attitudes, whose comparisons can address territorial policies on both a local and provincial scale. Furthermore, the focus on the "cities network" is here assumed and proposed as the privileged point of observation of territory and the related aspects of the quality of life.

Keywords: social-territorial disadvantage; inner land areas; land-urban multidimensional analysis; land urban economies; multicriteria analysis; land real estate market values

\section{Introduction}

This paper is framed within a wider research project concerning the territorial disadvantage characterizing the inner land areas compared to the coastal metropolitan areas of Sicilia (Italy). On a wider scale (regional and national), these criticalities are due to the competition between territorial administrative units, which has been aggravating the territorial and socioeconomic imbalance in these territories.

This study aims at outlining an inter-scalar and multi-polar analysis evaluation model of the territory of the Province of Enna, Italy, (Figure 1), supporting a consistent axiological representation of the most relevant features of the territorial imbalance from the perspective of the human and urban capital asset that value they express.

Concerning these two forms of the social capital-and specifically regarding the effects of the progressive weakening of the former on the decaying of the latter-it should be noticed that all the components of the GDP (Gross Domestic Product) are involved in the displacement of the population towards the more developed urban areas. 


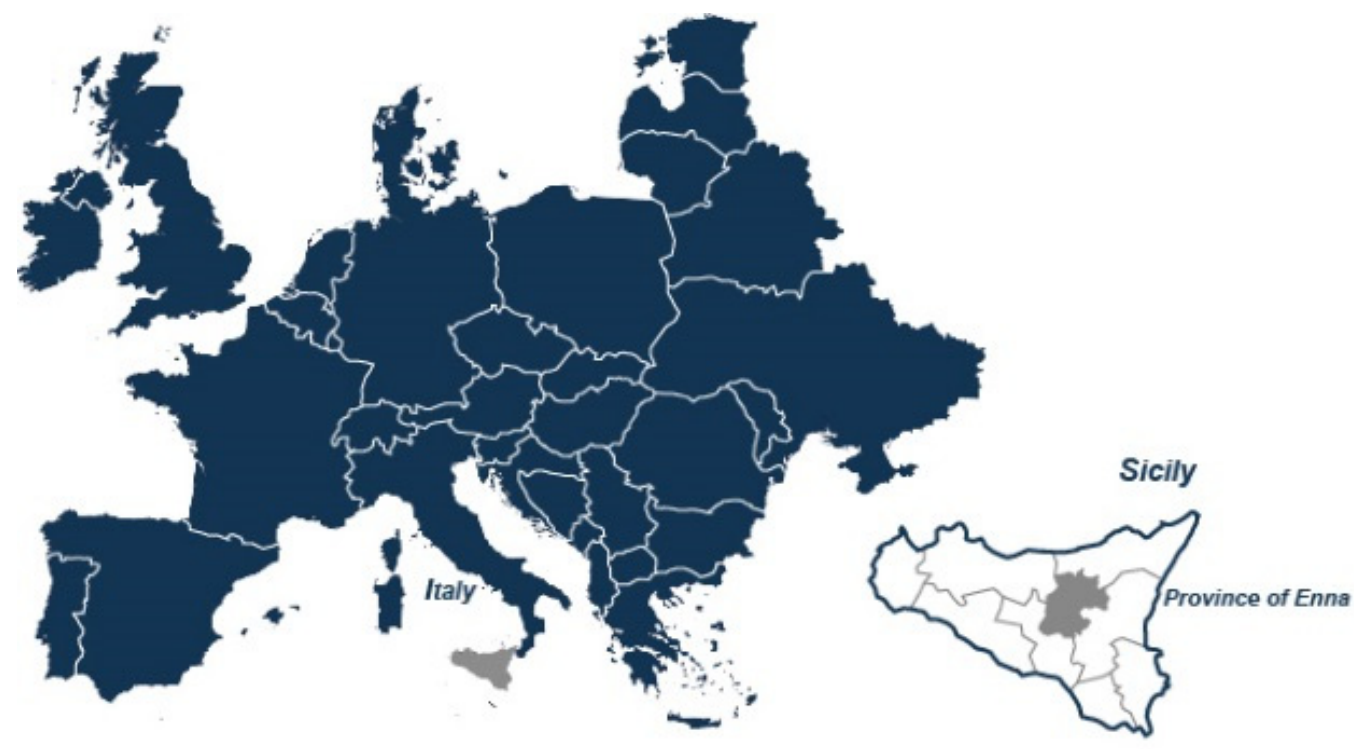

Figure 1. Geographic location of the Province of Enna.

New socio-economic prospects, which are as follows have been progressively transferred towards the richer areas: a greater supply of cheap labor, knowledge and skills, as well as-more recently-excellence; the increase in the demand for goods, services, and housing and payment of taxes. In addition, new public and private investments have been encouraged in the more developed territories and cities, whose companies have extended their market areas over the undeveloped ones. In fact, the progressively increasing territorial dis-equilibrium has been favoring the penetration of the weaker markets by these companies, which are also more likely to become monopolies due to the opportunity of differentiating their production, especially by practicing the "damaging quality", to the detriment of the peripheral markets.

Concerning the integration of territorial (public and environmental) values and specific (local or private interests) ends, converging on the land, Colavitti et al. [1] remarked upon the prominent role of the urban general plan in respect to so-called "strategic planning", which has replaced ends with means, and therefore fairness with cost-effectiveness and financial feasibility. The financialization of the real estate sector has extended access to real estate even to "non-owners", thus increasing the ability of the real estate sector itself to influence planning. More generally, the new trends in the real estate sector stand out as one of the ways in which the economic sub-system prevails over the political one. As a result, real estate development does not integrate into the landscape. Furthermore, the authors, identify the cities network as the decisional interface between local development and global sustainability, as well as between the instances of urban capital assets and the shared prospects of human capital, namely, the environmental ones.

The environmental prospect of the relation between the urban and human dimensions of the social capital asset-meant as the part of the global social product that has been accumulating overtime in "artifacts and institutions" - has been sampled by Esposito et al. [2] by analyzing "the effects of the tertiarization process on urbanization-driven land consumption and the extent to which it can explain the complex relationship between growth and environment". This is one of the most relevant risks that the weak territories run, and, once more, evidence of the prevailing effects of economic drivers over the political capacity to drive territorial development toward a landscape perspective. One of the most significant effects of economic growth regarding the relation between cities and territories is soil consumption, measuring the needs for locating housing, facilities, industrial assets and the related infrastructures. The authors find that the tertiarization of the economyfocusing on quality and services, rather than on quantity and goods-can contain soil consumption, thus standing as a more sustainable form of economic growth. 
The transformation of the relationship between city and territory, driven by economic growth and the progress of private, public and integrated mobility, has always been interpreted considering the way populations and economies have been concentrated in dense areas or spread out in the rarefied space beyond the peripheries, according to the concepts of urbanization, suburbanization, counter-urbanization and re-urbanization [3].

Structural aspects of progressive socio-economic polarization, long-term environmental transformations and cyclical environmental fluctuations, such as natural disasters and pandemics, continue to stimulate the debate on new integrated localization models and the transformation of work and social relations that could be driven by digitalization, which encourage the repopulation of small abandoned urban centers.

This perspective is encouraged by the generalized recognition of the environmental issue, the overwhelming evidence for which has imposed the need for a progressive and structural ecological transition, triggered by unprecedented financial intervention by central governments, and by the prospect of initiating structural reforms in all strategic sectors of the state administration: taxation, health, basic training, research, land management, innovation, energy and digitalization.

As a specification of these wide prospects, this study proposes to identify the environmental issues affecting the relation between the city network and the territory as the set of circumstances leading to territorial-urban identity loss.

The thematic area of this research concerns the territorial imbalance in its problematic articulations in terms of "abandoned territories", "internal areas", "houses for one euro" etc. [4-16].

Due to their complexity, these phenomena are usually seen through the thin opening of each of the different disciplinary niches that overlook them; each of them captures different specialized aspects connected, in turn, to the general perspectives of each disciplinary root: health, safety, sustainability, inclusion, responsibility, well-being etc.

The built heritage of the small hilly and mountainous towns-now inhabited by a few dozen families, mostly by the elderly-is characterized by "strong identity features which, however, seem to be heading towards extinction" [17].

The growing interest in the phenomenon of the abandonment of inland areas is also confirmed by the specialist literature, with multiple contributions on the topic of small urban centers [18-21] trying to interpret the causes of this phenomenon and propose redevelopment strategies.

The 2030 Agenda for Sustainable Development provides general measures regarding less developed areas ("11.c: Supporting less developed towns, possibly also providing technical and financial assistance, in constructing sustainable and resilient buildings using local materials") [22,23] in the view of the prominent role that culture and heritage can play in sustainable development [24].

The Report on "Historic centres and the future of the country" from ANCSA (National Association of Historic-Artistic Centers) [25] provides an analysis of the vulnerability/resilience relationship of the 109 historic centers to the Italian provincial capitals. It provides rankings on the main 8000Census indices from ISTAT (Italian National Institute of Statistic) relating to population dynamics, the composition of families, the aging of residents, the integration of foreigners, the adequacy of housing and employment. The comparisons between the indices calculated on the scale of the historic center and those relating to the rest of the municipal area, with reference to the average data on a national scale, are also of great interest [26-36].

The same study identifies guidelines regarding the enhancement of the relational space of the assets concerned and of the values at risk. The network of the historic centers is identified as a territorial component "subject to integrated and coherent policies and interventions aimed at sustainability, preservation, regeneration" [37-65].

More generally, the ANCSA analysis underlines an overall lack of studies on historic centers: this is due both to the non-recognition of the economic value of this heritage, and the lack of coordination between institutions and regulations [25]. 
From the latter point of view, the study reports the ineffectiveness of some tools, specifically those aimed at small historic centers in inland areas, including the law of 31 January 1994 (law no. 97 "New provisions for mountain areas") [66]. On the other hand, the most recent "Law to save villages", 6 October 2017, n. 158 "Measures for the support and enhancement of small municipalities, as well as provisions for the redevelopment and recovery of the historic centers of the same municipalities" aims to support, through incentives, the development of small municipalities [67], even if, to date, it is cumbersome to apply (Decree of the Ministry of the Interior 10 August 2020) [68].

Although the ANCSA report is of great interest, it does not concern fragile territories, in particular small municipalities, focusing only on the provincial capitals [25].

The question of inland areas, as regards the relationship between historic centers, building expansion areas and rural territory, needs to be re-observed and reinterpreted within territorial and cultural contexts united by evident conditions of territorial disadvantage [69-73].

According to the recognized territorial and urban context value of these land units, planning is urged to identify and activate common strategies for all historic centers by creating new models and values-lifestyles and opportunities for meeting and exchangesin an ancient site, home to knowledge, culture and traditions, thus removing it from oblivion and silence [74-83].

The identification and recognition of the values from which to re-start are the premises of a new perspective on economic and social development for the reduction of territorial disadvantage [84-105].

By identifying the peculiarities, opportunities and criticalities of the territories, it is possible to re-inhabit the built heritage, as well as to re-build and re-live the social heritage of which it is a part [106-109].

As for the issue of territorial disadvantage, the scope of the rebalancing policy known as the National Strategy for Internal Areas (NSIA) provides for support measures for the benefit of the territories affected by structural processes of depopulation and abandonment (1077 Italian municipalities and just over 2 million inhabitants) [110].

The problematic framework of this dilemma is articulated, in Italy, in the southern question, in the condition of the marginalization of disadvantaged areas, in the effects of territorial competition on all scales, in the city/countryside polarization, in the consequent "rurbanization" (that is the urbanization of the countryside) and in the more recent repolarization between large metropolitan areas and "second-class" territorial-urban fabrics. GDP, again, makes the real difference [111].

And COVID-19? One of the irreversible effects of home segregation in pandemic times was the crisis of the myth of human concentration in the small urban circumference, a myth that crumbled down when public space and, with it, human contact began to constitute not only a danger, but also the only target of the counter-offensive to the virus, which aimed to defend people and communities from contagion, as well as activities and economies from collapse [112,113].

Even the openly (neo) liberal political systems did not hesitate to practice a war economy with authoritarian accents and centralist economic measures [114].

This is the background of this study on structured observation (data, information, indices, evaluations, correlations, interpretations) [115-121], by means of which it is possible to describe and represent the aspects of the "house-city-landscape system" at the provincial scale that are relevant in light of the possible relationships between the "armor" of the cities and the territory, in a turning point in which-precisely with reference to those municipalities that are becoming the symbols of the return to a more human urban dimension-the scientific, economic and social community seeks the drivers of the hope that the tendency to abandonment can effectively-and in the short-medium term-be reversed.

In such a prospect, in fact, the city is more appropriately considered as a "condition", or a "way of being", rather than a mere territorial entity. As such, the urban condition has been assumed as a "sign" in a broader semantic field, within which it becomes the most 
significant explanatory unit of territory, which is, by definition, a social entity less dense in terms of "events" and "abilities to be worth". The latter, in fact, are the drivers for the inversion of the development model outlined by the ecological transition: synergy between nature and culture, continuity of the house-city-landscape system, social inclusion and finally process integration as both an explanatory and planning premise.

The paper is organised into six sections:

- Section 2 presents the case study, starting from an overview of the general status of the overall land district of Enna as a whole and an in-depth analysis of the main territorial, societal, economic etc. characteristics of the municipalities;

- Section 3 introduces the methodological approach, proposing a hierarchical multidimensional model coordinating the five forms of the social-territorial capital asset;

- Section 4 describes the application in its double articulation: firstly on the scale of the cities network, and secondly on the scale of the city-territory relationship;

- Sections 5 and 6 propose some reflections on the centrifugal approach from city to territory, and about the role of evaluation within the overall analysis valuation planning-process in the face of the complexity of the redevelopment plan for the mitigation of territorial disadvantage.

\section{Materials}

\subsection{The Study Area: General Issues}

The object of this research is the representation of the value characteristics of the network of the 20 cities in the territory of the province of Enna defined by means of the extensive interweaving of territorial data representative of multiple conditions: human (population); material (housing); economic (production and work); real estate (volumes and prices) and income (income per capita). Such a representation is carried out by means of scoring, comparisons and rankings of the municipalities of this district.

The latter-despite the generally relevant abandonment phenomenon $(-31 \%$ during the last 70 years) - still holds the most part of its own population within the urban centers. Due to the orography of the territory, which is mainly mountainous and characterized by the ridges of the Nebrodi, Erei and Madonie chains, the province of Enna has many of the typical characteristics of the urban centers of inland areas. These criticalities are part of the concern of the national territorial rebalancing policy known as the National Strategy of Internal Areas (NSIA), aimed at implementing support measures for the benefit of the territories affected by structural processes of depopulation and abandonment: this condition concerns 1077 of the 7904 municipalities in Italy, with a total of 2 million inhabitants. In particular, the territory of the province of Enna is excluded from the NSIA, although there are recognizable aspects of fragility, some of them demographic (Figures 1 and 2), economic and dimensional, as seven out of 20 municipalities can be considered as "small town centers", therefore having less than 5000 inhabitants.

NSIA is "a place-based policy project, in which new ways of multilevel local governance are committed to an integrated approach oriented towards promotion and local development" [122]. The goal is to foster unexpressed local potentialities in accordance with the enhancement of the specificities (or uniqueness) of the local communities. In these territories, the most critical profiles of fragility and difficult accessibility have, on the one hand, strongly compressed the possibilities of adapting to the standards of contemporary lifestyles, while on the other hand they have been preserving a sort of "constitutive inertia". This resistance to transformation is due to genuine features that make these urban and landscape contexts stand out and justify differently valid reasons for remaining or returning there. 
Resident in the UA

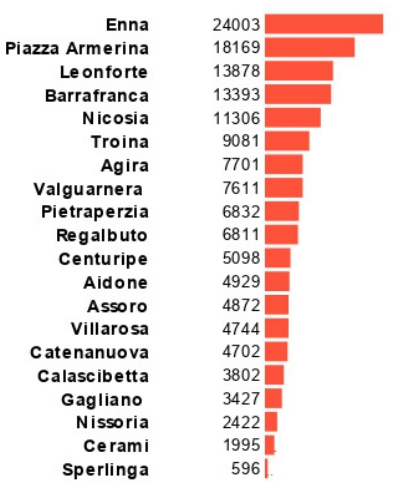

Population density in $\mathrm{HC}$

\begin{tabular}{|c|c|}
\hline Centuripe & $89 \%$ \\
\hline Valguarnera & $67 \%$ \\
\hline Agira & $66 \%$ \\
\hline Piazza Armerina & $43 \%$ \\
\hline Regalbuto & $42 \%$ \\
\hline Villarosa & $41 \%$ \\
\hline Cerami & $39 \%$ \\
\hline Nicosia & $34 \%$ \\
\hline Calascibetta & $33 \%$ \\
\hline Troina & $33 \%$ \\
\hline Assoro & $32 \%$ \\
\hline Gagliano & $30 \%$ \\
\hline Leonforte & $28 \%$ \\
\hline Nissoria & $26 \%$ \\
\hline Enna & $23 \%$ \\
\hline Sperlinga & $21 \%$ \\
\hline Pietraperzia & $20 \%$ \\
\hline Aidone & $16 \%$ \\
\hline Barrafranca & $5 \%$ \\
\hline Catenanuova & $3 \%$ \\
\hline
\end{tabular}

\% High education degree

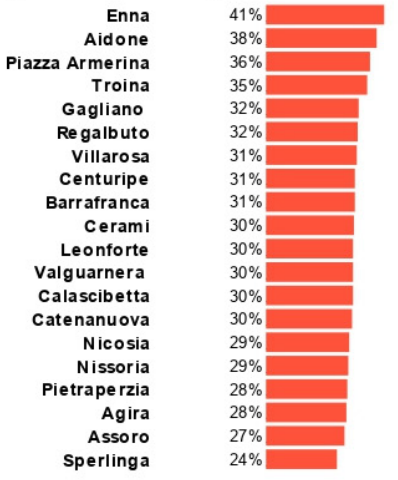

Building cubage index PA

$\begin{array}{rr}\text { Catenanuova } & 0,064 \\ \text { Valguarnera } & 0,053 \\ \text { Barrafranca } & 0,043 \\ \text { Pietraperzia } & 0,019 \\ \text { Leonforte } & 0,016 \\ \text { Villarosa } & 0,014 \\ \text { Piazza Armerina } & 0,012 \\ \text { Enna } & 0,012 \\ \text { Gagliano } & 0,010 \\ \text { Troina } & 0,009 \\ \text { Nicosia } & 0,009 \\ \text { Nissoria } & 0,009 \\ \text { Calascibetta } & 0,008 \\ \text { Re galbuto } & 0,008 \\ \text { Assoro } & 0,006 \\ \text { Agira } & 0,005 \\ \text { Cerami } & 0,004 \\ \text { Sperlinga } & 0,004 \\ \text { Aidone } & 0,004 \\ \text { Centuripe } & 0,001 \mid\end{array}$

Population density in UA

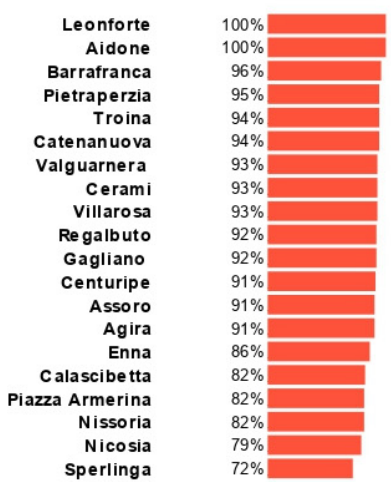

Old age index

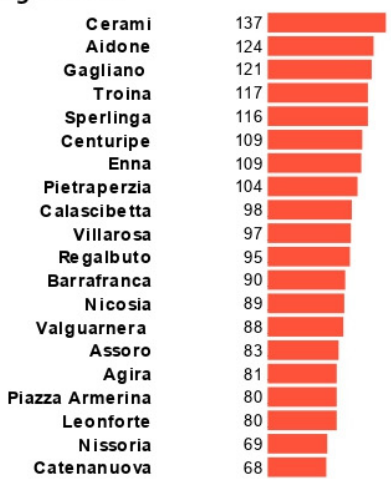

Families average components

$$
\begin{array}{r}
\text { Leonforte } \\
\text { Barrafranca } \\
\text { Aidone } \\
\text { Catenanuova } \\
\text { Valguarnera } \\
\text { Villarosa } \\
\text { Pietraperzia } \\
\text { Assoro } \\
\text { Troina } \\
\text { Agira } \\
\text { Re galbuto } \\
\text { Enna } \\
\text { Gagliano } \\
\text { Centuripe } \\
\text { Calascibetta } \\
\text { Nicosia } \\
\text { Cerami } \\
\text { Nissoria } \\
\text { Armerina } \\
\text { Sperlinga }
\end{array}
$$

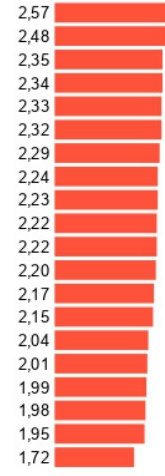

Occupied housing surface ind UA

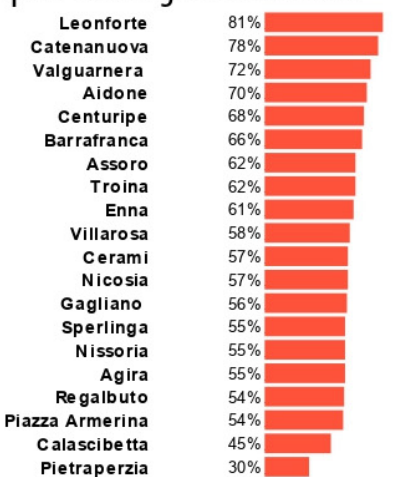

Residents in the $\mathrm{HC}$

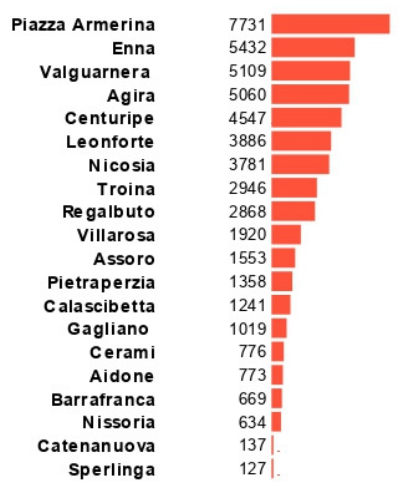

Average age UA

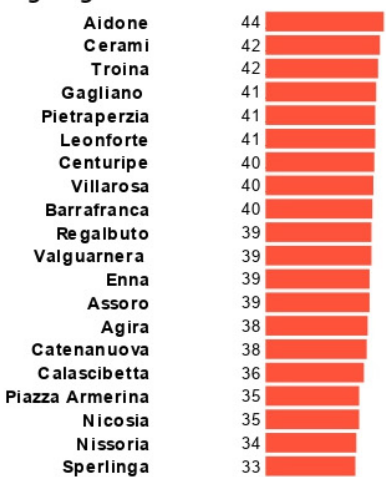

Building cubage index $\mathrm{HC}$

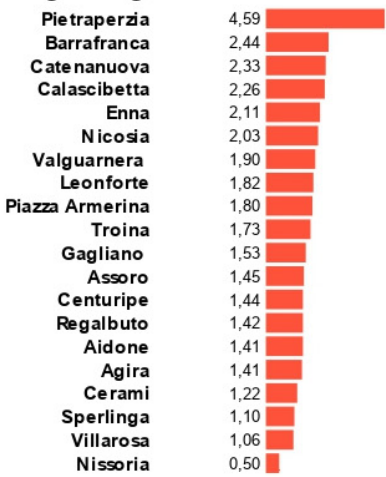

Occupied housing surface ind CS

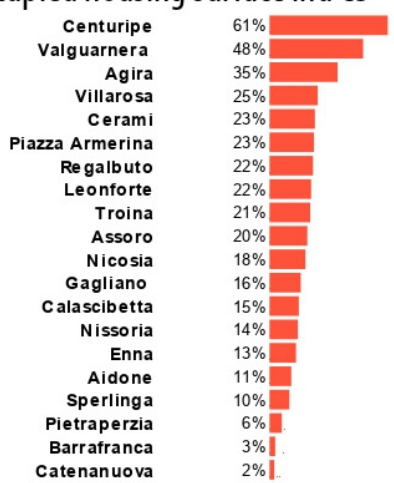

Figure 2. Rankings of the Municipalities from the perspective of the location territorial equilibrium indices. 
This perspective has supported the interest in this investigation, and the attempt to effectively organize the large amount of data from official sources. The robustness of these information profiles is entrusted to the fundamental categories of the science of economicterritorial evaluations (Appraisal) and to the more general economic category of capital. The category of capital assets is expressed in the two dimensions of value, the ability to supply flows of wealth (goods and services of various kinds) and the possibility that these flows accumulate and consolidate in stock-value.

These distinctive/assumptive categories are also applied with the same explanatory appropriateness to non-monetary value dimensions, and for this reason six different dimensions have been selected and described.

The set of surveys involved the entire provincial territory, though with different levels of detail and therefore with reference to study units on three different scales.

As mentioned, the priority interest in cities networks - and the prospect of further studies on historic centers that outline the reasons for "remaining/returning" [123] —has reversed the method of territorial investigation that began with the consideration of more detailed territorial units, namely, the Census Sections (SC). As a result, two areas of observation were identified:

- Multiscale, with reference to the scale of the census sections of the cadastral microzones and municipalities;

- Multidimensional [124], with reference to the six forms of territorial capital, that is, the different ability to be worth $[125,126]$ expressed by the territorial units analyzed.

\subsection{Early Overview of The Data Source}

In a general sense, the following observations are aimed at suggesting an interpretative scheme of the weakening of historic centers with respect to the peripheral areas, of recent construction and with lower building density, which have been considered as some of the main premises of the urban good life in the more general background of territorial values.

The building density, if calculated with reference to the surface of the Census Sections, is very low, and this could be one of the reasons for the abandonment of old dwellings in favour of more accessible and open locations.

The indices that measure the location preference between Historic Center $(\mathrm{HC})$ and Peripheral Areas (PA) of the Urban Area (UA). such as the Surface of occupied dwellings in the UA and CS, can be considered as:

- Complementary on the one hand, if the local inhabitants tend to move from CS to the more preferable life quality of the PA; in such a case, the discomfort attributable to the conditions of life in the HC as well as new opportunities in the PA converge, supporting an internal re-location pattern;

- Converging on the other hand, if the whole local and extra-local area is affected by a structural abandonment trend due to a deeper socio-economic discomfort, a general disaffection with traditional lifestyles, poor prospects for individual promotion and the desire for a relational space with a metropolitan imprint.

Two of the most relevant criticalities of this land district are indicated as follows.

Table 1 shows the population dynamics in the 20 municipalities since 1951, as well as the clear prevalence of Enna and Piazza Armerina, the only ones that exceed 20,000 inhabitants. Only three of the other municipalities exceed 10,000 inhabitants, while 9 municipalities have less than 5000 inhabitants. 
Table 1. Population dynamics in the 20 Municipalities of the Enna District.

\begin{tabular}{cccccccc}
\hline & $\mathbf{1 9 5 1}$ & $\mathbf{1 9 6 1}$ & $\mathbf{1 9 7 1}$ & $\mathbf{1 9 8 1}$ & $\mathbf{1 9 9 1}$ & $\mathbf{2 0 0 1}$ & $\mathbf{2 0 1 6}$ \\
\hline Agira & 16,528 & 14,079 & 11,814 & 9146 & 9150 & 8348 & 8301 \\
Aidone & 10,106 & 8905 & 7551 & 7136 & 7275 & 6057 & 4852 \\
Assoro & 5563 & 5663 & 5167 & 5236 & 5319 & 5393 & 5135 \\
Barrafranca & 14,665 & 14,775 & 14,447 & 15,511 & 13,667 & 13,115 & 13,212 \\
Calascibetta & 8035 & 6956 & 5628 & 4837 & 5014 & 4829 & 4493 \\
Catenanuova & 3993 & 4406 & 4121 & 4420 & 5073 & 4876 & 4798 \\
Centuripe & 11,020 & 10,008 & 8172 & 6915 & 6612 & 5903 & 5416 \\
Cerami & 4652 & 4371 & 3427 & 3182 & 3100 & 2462 & 1979 \\
Enna & 27,263 & 28,323 & 28,189 & 27,838 & 28,273 & 28,983 & 27,586 \\
Gagliano & 5075 & 4846 & 4459 & 4172 & 4173 & 3772 & 3554 \\
Leonforte & 18,391 & 17,927 & 16,364 & 15,808 & 15,147 & 14,145 & 13,305 \\
Nicosia & 19,275 & 18,191 & 15,324 & 15,212 & 15,029 & 14,812 & 13,762 \\
Nissoria & 3438 & 3115 & 3032 & 3296 & 3152 & 3014 & 2992 \\
Piazza Armerina & 26,739 & 24,887 & 22,134 & 21,019 & 22,355 & 21,038 & 21,782 \\
Pietraperzia & 13,886 & 13,226 & 11,026 & 10,996 & 8015 & 7340 & 6919 \\
Regalbuto & 11,768 & 11,239 & 10,159 & 7621 & 7981 & 7744 & 7233 \\
Sperlinga & 1552 & 1432 & 1216 & 1053 & 1065 & 963 & 783 \\
Troina & 14,075 & 13,066 & 11,853 & 11,052 & 10,406 & 10,061 & 9310 \\
Valguarnera & 15,592 & 13,829 & 11,167 & 10,252 & 9171 & 8649 & 7774 \\
Villarosa & 11,059 & 9882 & 6881 & 6237 & 6205 & 5696 & 4866 \\
\hline
\end{tabular}

Table 2 summarizes the ten-year percentage demographic balances, which are negative in most of the 20 cities except for Enna $(+0.2 \%)$ and Catenanuova $(+3.4 \%)$. In the face of these modest increases, considerable decreases stand out in all the other municipalities (min $-12.9 \%$, 1st quartile $-10.6 \%$, median $-7.0 \%$, 3rd quartile $-2.9 \%$, max $3.4 \%$ )

Table 2. 10-Years population variation rates in Enna District.

\begin{tabular}{|c|c|c|c|c|c|c|c|}
\hline & 1951-1961 & 1961-1971 & 1971-1981 & 1981-1991 & 1991-2001 & 2001-2016 & Average \\
\hline Agira & $-14.8 \%$ & $-16.1 \%$ & $-22.6 \%$ & $0.0 \%$ & $-8.8 \%$ & $-0.6 \%$ & $-10.5 \%$ \\
\hline Aidone & $-11.9 \%$ & $-15.2 \%$ & $-5.5 \%$ & $1.9 \%$ & $-16.7 \%$ & $-19.9 \%$ & $-11.2 \%$ \\
\hline Assoro & $1.8 \%$ & $-8.8 \%$ & $1.3 \%$ & $1.6 \%$ & $1.4 \%$ & $-4.8 \%$ & $-1.2 \%$ \\
\hline Barrafranca & $0.8 \%$ & $-2.2 \%$ & $7.4 \%$ & $-11.9 \%$ & $-4.0 \%$ & $0.7 \%$ & $-1.5 \%$ \\
\hline Calascibetta & $-13.4 \%$ & $-19.1 \%$ & $-14.1 \%$ & $3.7 \%$ & $-3.7 \%$ & $-7.0 \%$ & $-8.9 \%$ \\
\hline Catenanuova & $10.3 \%$ & $-6.5 \%$ & $7.3 \%$ & $14.8 \%$ & $-3.9 \%$ & $-1.6 \%$ & $3.4 \%$ \\
\hline Centuripe & $-9.2 \%$ & $-18.3 \%$ & $-15.4 \%$ & $-4.4 \%$ & $-10.7 \%$ & $-8.3 \%$ & $-11.0 \%$ \\
\hline Cerami & $-6.0 \%$ & $-21.6 \%$ & $-7.1 \%$ & $-2.6 \%$ & $-20.6 \%$ & $-19.6 \%$ & $-12.9 \%$ \\
\hline Enna & $3.9 \%$ & $-0.5 \%$ & $-1.2 \%$ & $1.6 \%$ & $2.5 \%$ & $-4.8 \%$ & $0.2 \%$ \\
\hline Gagliano & $-4.5 \%$ & $-8.0 \%$ & $-6.4 \%$ & $0.0 \%$ & $-9.6 \%$ & $-5.8 \%$ & $-5.7 \%$ \\
\hline Leonforte & $-2.5 \%$ & $-8.7 \%$ & $-3.4 \%$ & $-4.2 \%$ & $-6.6 \%$ & $-5.9 \%$ & $-5.2 \%$ \\
\hline Nicosia & $-5.6 \%$ & $-15.8 \%$ & $-0.7 \%$ & $-1.2 \%$ & $-1.4 \%$ & $-7.1 \%$ & $-5.3 \%$ \\
\hline Nissoria & $-9.4 \%$ & $-2.7 \%$ & $8.7 \%$ & $-4.4 \%$ & $-4.4 \%$ & $-0.7 \%$ & $-2.1 \%$ \\
\hline Piazza Armerina & $-6.9 \%$ & $-11.1 \%$ & $-5.0 \%$ & $6.4 \%$ & $-5.9 \%$ & $3.5 \%$ & $-3.2 \%$ \\
\hline Pietraperzia & $-4.8 \%$ & $-16.6 \%$ & $-0.3 \%$ & $-27.1 \%$ & $-8.4 \%$ & $-5.7 \%$ & $-10.5 \%$ \\
\hline Regalbuto & $-4.5 \%$ & $-9.6 \%$ & $-25.0 \%$ & $4.7 \%$ & $-3.0 \%$ & $-6.6 \%$ & $-7.3 \%$ \\
\hline Sperlinga & $-7.7 \%$ & $-15.1 \%$ & $-13.4 \%$ & $1.1 \%$ & $-9.6 \%$ & $-18.7 \%$ & $-10.6 \%$ \\
\hline Troina & $-7.2 \%$ & $-9.3 \%$ & $-6.8 \%$ & $-5.8 \%$ & $-3.3 \%$ & $-7.5 \%$ & $-6.6 \%$ \\
\hline Valguarnera & $-11.3 \%$ & $-19.2 \%$ & $-8.2 \%$ & $-10.5 \%$ & $-5.7 \%$ & $-10.1 \%$ & $-10.9 \%$ \\
\hline Villarosa & $-10.6 \%$ & $-30.4 \%$ & $-9.4 \%$ & $-0.5 \%$ & $-8.2 \%$ & $-14.6 \%$ & $-12.3 \%$ \\
\hline
\end{tabular}

Table 3 shows the population variation rates in progressively decreasing time periods up to the period 2001-2016 and the average rates. 
Table 3. Progressive population variation rates in the District of Enna.

\begin{tabular}{|c|c|c|c|c|c|c|c|}
\hline & 1951-2016 & 1961-2016 & 1971-2016 & 1981-2016 & 1991-2016 & 2001-2016 & Average \\
\hline Agira & $-49.8 \%$ & $-41.0 \%$ & $-29.7 \%$ & $-9.2 \%$ & $-9.3 \%$ & $-0.6 \%$ & $-23.3 \%$ \\
\hline Aidone & $-52.0 \%$ & $-45.5 \%$ & $-35.7 \%$ & $-32.0 \%$ & $-33.3 \%$ & $-19.9 \%$ & $-36.4 \%$ \\
\hline Assoro & $-7.7 \%$ & $-9.3 \%$ & $-0.6 \%$ & $-1.9 \%$ & $-3.5 \%$ & $-4.8 \%$ & $-4.6 \%$ \\
\hline Barrafranca & $-9.9 \%$ & $-10.6 \%$ & $-8.5 \%$ & $-14.8 \%$ & $-3.3 \%$ & $0.7 \%$ & $-7.7 \%$ \\
\hline Calascibetta & $-44.1 \%$ & $-35.4 \%$ & $-20.2 \%$ & $-7.1 \%$ & $-10.4 \%$ & $-7.0 \%$ & $-20.7 \%$ \\
\hline Catenanuova & $20.2 \%$ & $8.9 \%$ & $16.4 \%$ & $8.6 \%$ & $-5.4 \%$ & $-1.6 \%$ & $7.8 \%$ \\
\hline Centuripe & $-50.9 \%$ & $-45.9 \%$ & $-33.7 \%$ & $-21.7 \%$ & $-18.1 \%$ & $-8.3 \%$ & $-29.7 \%$ \\
\hline Cerami & $-57.5 \%$ & $-54.7 \%$ & $-42.3 \%$ & $-37.8 \%$ & $-36.2 \%$ & $-19.6 \%$ & $-41.3 \%$ \\
\hline Enna & $1.2 \%$ & $-2.6 \%$ & $-2.1 \%$ & $-0.9 \%$ & $-2.4 \%$ & $-4.8 \%$ & $-2.0 \%$ \\
\hline Gagliano & $-30.0 \%$ & $-26.7 \%$ & $-20.3 \%$ & $-14.8 \%$ & $-14.8 \%$ & $-5.8 \%$ & $-18.7 \%$ \\
\hline Leonforte & $-27.7 \%$ & $-25.8 \%$ & $-18.7 \%$ & $-15.8 \%$ & $-12.2 \%$ & $-5.9 \%$ & $-17.7 \%$ \\
\hline Nicosia & $-28.6 \%$ & $-24.3 \%$ & $-10.2 \%$ & $-9.5 \%$ & $-8.4 \%$ & $-7.1 \%$ & $-14.7 \%$ \\
\hline Nissoria & $-13.0 \%$ & $-3.9 \%$ & $-1.3 \%$ & $-9.2 \%$ & $-5.1 \%$ & $-0.7 \%$ & $-5.5 \%$ \\
\hline Piazza Armerina & $-18.5 \%$ & $-12.5 \%$ & $-1.6 \%$ & $3.6 \%$ & $-2.6 \%$ & $3.5 \%$ & $-4.7 \%$ \\
\hline Pietraperzia & $-50.2 \%$ & $-47.7 \%$ & $-37.2 \%$ & $-37.1 \%$ & $-13.7 \%$ & $-5.7 \%$ & $-31.9 \%$ \\
\hline Regalbuto & $-38.5 \%$ & $-35.6 \%$ & $-28.8 \%$ & $-5.1 \%$ & $-9.4 \%$ & $-6.6 \%$ & $-20.7 \%$ \\
\hline Sperlinga & $-49.5 \%$ & $-45.3 \%$ & $-35.6 \%$ & $-25.6 \%$ & $-26.5 \%$ & $-18.7 \%$ & $-33.5 \%$ \\
\hline Troina & $-33.9 \%$ & $-28.7 \%$ & $-21.5 \%$ & $-15.8 \%$ & $-10.5 \%$ & $-7.5 \%$ & $-19.6 \%$ \\
\hline Valguarnera & $-50.1 \%$ & $-43.8 \%$ & $-30.4 \%$ & $-24.2 \%$ & $-15.2 \%$ & $-10.1 \%$ & $-29.0 \%$ \\
\hline Villarosa & $-56.0 \%$ & $-50.8 \%$ & $-29.3 \%$ & $-22.0 \%$ & $-21.6 \%$ & $-14.6 \%$ & $-32.4 \%$ \\
\hline
\end{tabular}

Further aspects of the territorial-urban fragility related to population dynamics concern the housing occupation rate, based on which the different municipalities can be compared from the point of view of the abandonment trend; the latter is one of the fundamental and original drivers of the relationship between urban quality and quality of life, as it transforms significant portions of the built heritage, which is sometimes of significant architectural value, into empty shells and redundant forms.

The inversion of "price/value semantics" and "monetary symbolization"-which culminated in the real estate paradox of "one-euro houses"—overwhelmed the concreteness and iconicity of the house- that is to say, its "intrinsic value" as an artefact that "is worth in itself". On the supply side, the production, this value has become autonomous concerning the rarity of materials, components, specialist expertise and overall value of the building tradition. On the demand side, the use, this iconicity has been standing with reference to two basic aspects: functional, such as safety and symbolic, such as social identity, according to which the value of the house is the privileged means of self-representation; these two archetypes reflect on the different ways the relationships between construction system, typology and urban context become architectural language, showing the anthropological profile of local communities in the overall urban dimension, and therefore the forms of the social dialectic and the degree of common values and destinies.

The ISTAT sources relating to 2001 and 2006 on the census sections scale report data whose selection and combination provide the individual profile and the comparative framework of the different municipalities from the point of view of the "housing value" of the urban built heritage, analyzed with reference to densely built-up areas and, in more detail, to the historic centers.

Some data and attributes (in direct or normalized form) are reported aiming at an outlining the overall framework of the province territory, but from the point of view of the quality of the urban aggregates.

By projecting these observations onto a territorial scale, further connections and correlations between the urban and land dimensions have been carried out with reference to social, economic, entrepreneurial and real estate variables (Tables 4 and 5).

Table 4 shows the distribution of the Enna land district population between the 20 municipalities. 
Table 4. Data and indices concerning the distribution of the Enna land district population between the 20 municipalities.

\begin{tabular}{|c|c|c|c|c|c|c|}
\hline & $\begin{array}{c}\text { Residents in } \\
\text { UA }\end{array}$ & $\begin{array}{c}\text { Population } \\
\text { Concentration in } \\
\text { UA }\end{array}$ & $\begin{array}{c}\text { Residents in } \\
\text { HC }\end{array}$ & $\begin{array}{c}\text { Population } \\
\text { Concentration in } \\
\text { HC }\end{array}$ & $\begin{array}{c}\text { Old Age } \\
\text { Index UA (\%) }\end{array}$ & $\begin{array}{c}\text { Average Age } \\
\text { UA (years) }\end{array}$ \\
\hline Agira & 7701 & $91 \%$ & 5060 & $66 \%$ & 81 & 38 \\
\hline Aidone & 4929 & $100 \%$ & 773 & $16 \%$ & 124 & 44 \\
\hline Assoro & 4872 & $91 \%$ & 1553 & $32 \%$ & 83 & 39 \\
\hline Barrafranca & 13,393 & $96 \%$ & 669 & $5 \%$ & 90 & 40 \\
\hline Calascibetta & 3802 & $82 \%$ & 1241 & $33 \%$ & 98 & 36 \\
\hline Catenanuova & 4702 & $94 \%$ & 137 & $3 \%$ & 68 & 38 \\
\hline Centuripe & 5098 & $91 \%$ & 4547 & $89 \%$ & 109 & 40 \\
\hline Cerami & 1995 & $93 \%$ & 776 & $39 \%$ & 137 & 42 \\
\hline Enna & 24,003 & $86 \%$ & 5432 & $23 \%$ & 109 & 39 \\
\hline Gagliano & 3427 & $92 \%$ & 1019 & $30 \%$ & 121 & 41 \\
\hline Leonforte & 13,878 & $100 \%$ & 3886 & $28 \%$ & 80 & 41 \\
\hline Nicosia & 11,306 & $79 \%$ & 3781 & $33 \%$ & 89 & 35 \\
\hline Nissoria & 2422 & $82 \%$ & 634 & $26 \%$ & 69 & 34 \\
\hline Piazza Armerina & 18,169 & $82 \%$ & 7731 & $43 \%$ & 80 & 35 \\
\hline Pietraperzia & 6832 & $95 \%$ & 1358 & $20 \%$ & 104 & 41 \\
\hline Regalbuto & 6811 & $92 \%$ & 2868 & $42 \%$ & 95 & 39 \\
\hline Sperlinga & 596 & $72 \%$ & 127 & $21 \%$ & 116 & 33 \\
\hline Troina & 9081 & $94 \%$ & 2946 & $32 \%$ & 117 & 42 \\
\hline Valguarnera & 7611 & $93 \%$ & 5109 & $67 \%$ & 88 & 39 \\
\hline Villarosa & 4744 & $92 \%$ & 1920 & $40 \%$ & 97 & 40 \\
\hline
\end{tabular}

Table 5. Data and indices showing the distribution of the UA (Urban Area) population between SU (SUburbs) and HC (Historic Center).

\begin{tabular}{|c|c|c|c|c|c|c|}
\hline & $\begin{array}{c}\text { \% High } \\
\text { Education } \\
\text { Level UA }\end{array}$ & $\begin{array}{l}\text { Families Average } \\
\text { Components UA }\end{array}$ & $\begin{array}{l}\text { Building } \\
\text { Cubage } \\
\text { Index HC }\end{array}$ & $\begin{array}{l}\text { Building Cubage } \\
\text { Index SU }\end{array}$ & $\begin{array}{l}\text { \% Inhabited } \\
\text { Housing } \\
\text { Area in UA }\end{array}$ & $\begin{array}{c}\% \text { Inhabited } \\
\text { Housing } \\
\text { Area in HC }\end{array}$ \\
\hline Agira & $28 \%$ & 2.22 & 1.41 & 0.0045 & $55 \%$ & $35 \%$ \\
\hline Aidone & $38 \%$ & 2.35 & 1.41 & 0.0034 & $70 \%$ & $11 \%$ \\
\hline Assoro & $27 \%$ & 2.24 & 1.45 & 0.0059 & $62 \%$ & $20 \%$ \\
\hline Barrafranca & $31 \%$ & 2.48 & 2.44 & 0.0424 & $66 \%$ & $3 \%$ \\
\hline Calascibetta & $30 \%$ & 2.04 & 2.26 & 0.0073 & $45 \%$ & $15 \%$ \\
\hline Catenanuova & $30 \%$ & 2.34 & 2.33 & 0.0635 & $78 \%$ & $2 \%$ \\
\hline Centuripe & $31 \%$ & 2.15 & 1.44 & 0.0007 & $68 \%$ & $61 \%$ \\
\hline Cerami & $30 \%$ & 1.99 & 1.22 & 0.0031 & $57 \%$ & $23 \%$ \\
\hline Enna & $41 \%$ & 2.20 & 2.11 & 0.0107 & $61 \%$ & $13 \%$ \\
\hline Gagliano & $32 \%$ & 2.17 & 1.53 & 0.0088 & $56 \%$ & $16 \%$ \\
\hline Leonforte & $30 \%$ & 2.57 & 1.82 & 0.0148 & $81 \%$ & $21 \%$ \\
\hline Nicosia & $29 \%$ & 2.01 & 2.03 & 0.0078 & $56 \%$ & $18 \%$ \\
\hline Nissoria & $28 \%$ & 1.98 & 0.49 & 0.0074 & $55 \%$ & $14 \%$ \\
\hline Piazza Armerina & $36 \%$ & 1.95 & 1.80 & 0.0108 & $54 \%$ & $23 \%$ \\
\hline Pietraperzia & $28 \%$ & 2.29 & 4.59 & 0.0174 & $30 \%$ & $6 \%$ \\
\hline Regalbuto & $32 \%$ & 2.21 & 1.42 & 0.0062 & $54 \%$ & $22 \%$ \\
\hline Sperlinga & $24 \%$ & 1.72 & 1.10 & 0.0021 & $55 \%$ & $10 \%$ \\
\hline Troina & $35 \%$ & 2.23 & 1.72 & 0.0074 & $62 \%$ & $21 \%$ \\
\hline Valguarnera & $30 \%$ & 2.33 & 1.90 & 0.0514 & $72 \%$ & $48 \%$ \\
\hline Villarosa & $31 \%$ & 2.32 & 1.06 & 0.0119 & $58 \%$ & $25 \%$ \\
\hline
\end{tabular}

Table 5 displays the comparison between the towns belonging to this territorial community from the perspective of the population concentration rate within the urban areas and old towns related to two age indices. These early findings significantly depend on the general territorial structure of each municipality-land surface size, number of inhabitants, orography, accessibility etc. so that they have been successively connected to the structured 
mass of the further information characterizing towns and municipalities, from the points of view of the five forms of capital identified.

This early observation shows a possible correlation between the number of residents and their distribution within the municipal territory, and a lower concentration in the main urban center. Similarly, the concentration of the population within the old towns is somehow connected to both the average old age of residents, and to the size of the recently developed areas compared to those of the old towns.

Table 5 provides a selection of the main information units connecting some societal issues to location preferences between the old towns and the peripheral urban areas (SU). This information cluster expresses weak trends of abandonment of the old towns likely connected with the higher rate of education (therefore to higher incomes) and to larger families.

Based on the different indicators reported in the above tables, the 20 Municipalities of the Enna Province are compared to each other by means of rankings displayed in the synopsis of Figure 2.

\subsection{Territory and Vulnerability}

A more general overview of territory, assumed here as the overall background of a global concept of life quality, comes from the judgment on vulnerability provided by the Italian National Institute of Statistic (ISTAT) through a special section, 8000Census, providing 99 information units (data and indices), referring to the census of the population and housing from 1951 to 2011, enriched with new sections and aggregated by themes: Population, Foreigners, Families, Housing, Education; Employment, Mobility, Vulnerability.

The 99 indicators selected make it possible to trace an unprecedented profile of the territory, both for the adoption of original indicators, capable of giving new responses to the need of knowledge for local government action (such as the social and material vulnerability index) and for the re-elaboration of more traditional indices, made comparable in historical series thanks to the reconstruction of the basic data [127-133].

The social and material vulnerability index is an indicator constructed with the aim of providing a synthetic measure of the level of social and material vulnerability of Italian municipalities.

It is a tool capable of expressing the different aspects of a multidimensional phenomenon with a single value, and which, thanks to its easy reading, facilitates territorial and temporal comparisons.

The index is constructed through the combination of seven elementary indicators that describe the main material and social dimensions of vulnerability. The values obtained, associated with the position in the national ranking, provide useful elements for identifying potential critical areas. The methodology used for the construction of the vulnerability index is based on the hypothesis of the non-"substitutability" of the various components, and allows the production of a synthetic index that is not compensatory and comparable over time in "absolute" terms.

The measurement of this phenomenon requires a preliminary conceptual definition, carried out through the decomposition of the general concept into its main components of meaning.

By social and material vulnerability we commonly mean the exposure of some segments of the population to risky situations, understood as the uncertainty of their social and economic condition. The index values measure different degrees of exposure among the population to vulnerable conditions that do not necessarily refer to an actual situation of hardship.

The main dimensions considered are degree of education, family structures, housing conditions, participation in the labour market and economic situation.

The territorial framework of vulnerability is represented in Figure 3, through a general map (on the left) and with specific maps for each of the eight matrices (on the right). Next 
to each map, the ranking of the 20 municipalities, referring to the theme represented, is displayed.

\section{a}

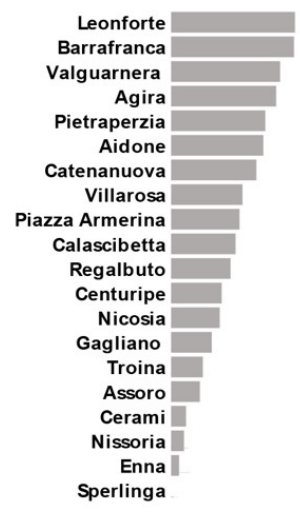

b
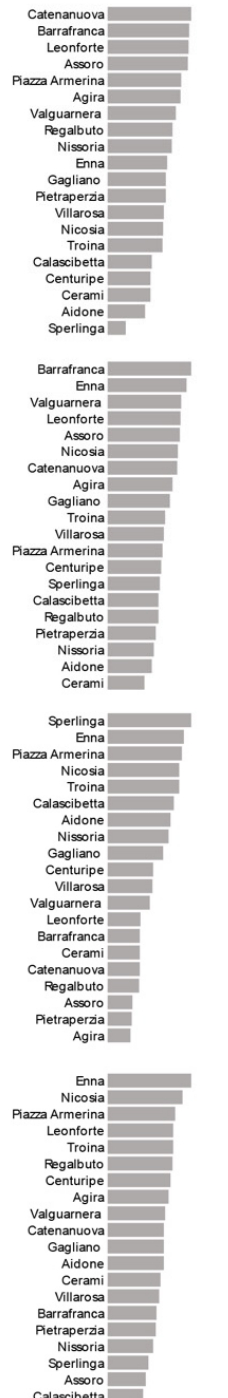
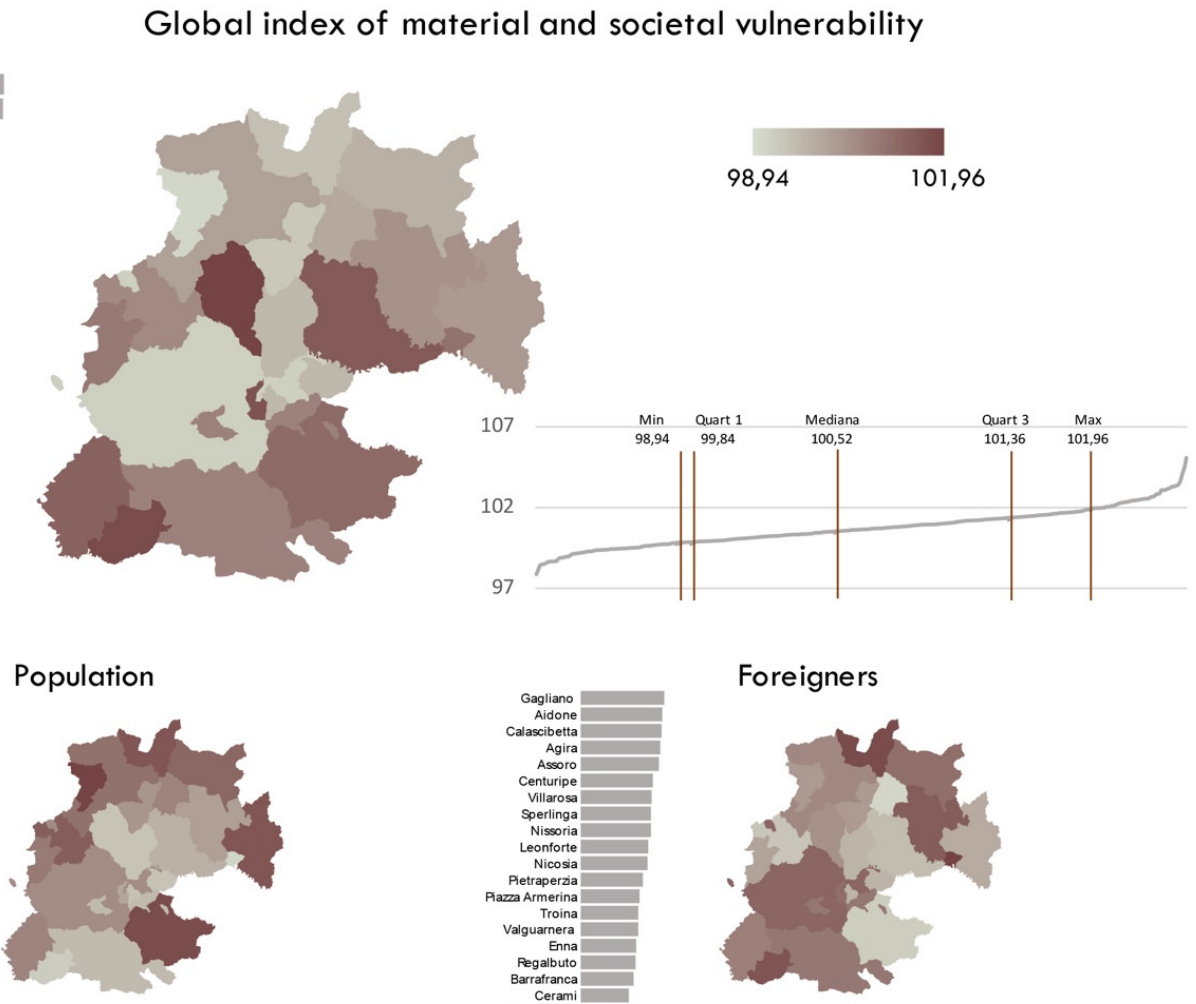

\section{Families}

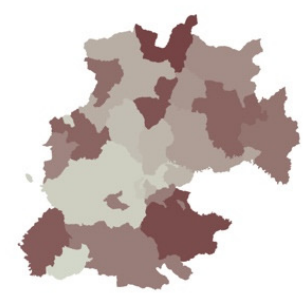

\section{Education}

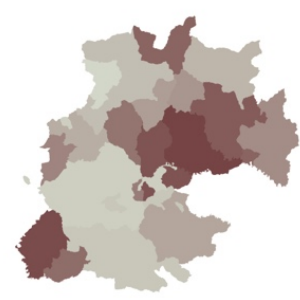

\section{Mobility}

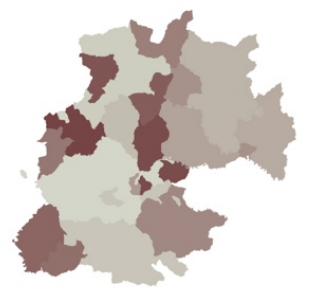

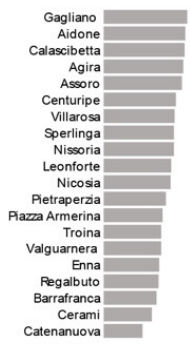
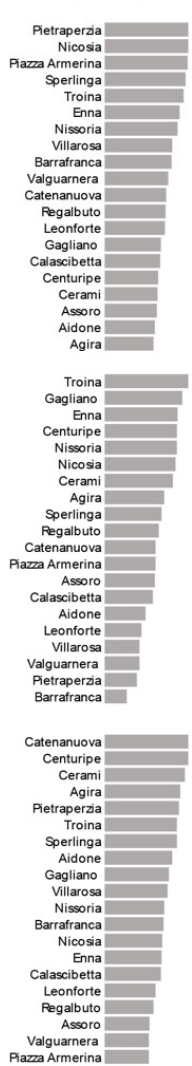

Foreigners

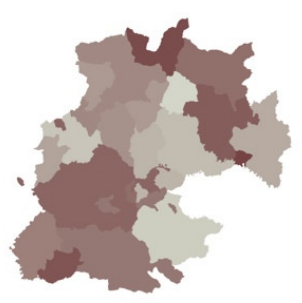

Housing

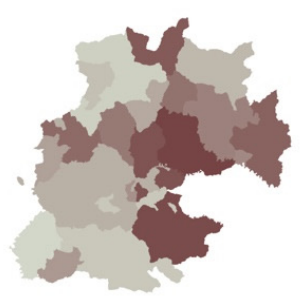

Employment

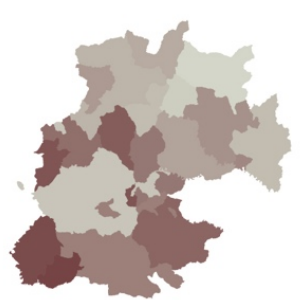

Vulnerability

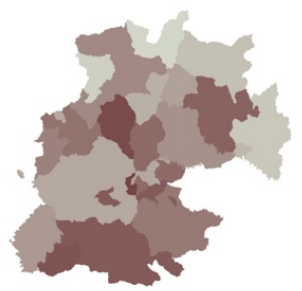

Figure 3. Rankings of the Municipalities from the perspective of the location territorial equilibrium indices (numerical values under the colour ramp): (a) overall score; (b) scores for each detailed index. 


\subsection{The Forms of the Land Capital Asset}

The dataset includes 464 elementary information units that express quantitative and qualitative absolute and relative measures (rates and indices), arranged in space and time and allowing comparisons between territorial units and progressively aggregated assessments, converging towards a more synthetic characterization of the territory articulated in the following five forms: human capital, economic capital, territorial capital, income capital and city capital.

\subsubsection{Human Capital Asset}

The characterization of the forms of Human Capital collects the 99 indicators in the 8000 Census section of the Istat, aimed at the assessment of material and social vulnerability and following its articulation regarding issues related to the population, the presence of foreigners, the size and composition of families, the adequacy of housing and the degree of education, work, mobility and vulnerability considered in a more specific sense.

\subsubsection{Economic Capital Asset}

The characterization of the forms of Economic Capital gathers 177 indicators ordered with reference to the Ateco 2007 aggregations of the sectors, which are as follows: primary, the Agricultural Capital; secondary, the Manufacturing Capital; tertiary, the Capital of Communication and quaternary, the capital of creativity.

\subsubsection{Income Capital}

The characterization of the forms of Territorial Capital in Volume and Value integrates the Istat database with that of the Real Estate Market Observatory of the Revenue Agency. In particular, reading through volumes integrates absolute and percentage measures relating to the physical size of the territories and their composition in terms of the degree of urbanization; the reading by values makes more specific reference to the building stock considering its testimonial value and therefore its age, and the economic value based on real estate prices in the articulation of the different types and OIREM (Observatory of the Italian Real Estate Market) Micro-zones.

\subsubsection{An In-Depth on Territorial Capital: The Real Estate Capital Asset}

A significant part of Territorial Capital, Real Estate Capital assets assume great importance both in epistemic and operative terms. In this research, this form of capital has been represented in its two forms, material and quantitative, with reference to the consistency of the patrimonial assets used for the calculation of the degree of transformation of the territory, and in its monetary form with reference to the official market prices provided for each homogeneous area and for each type.

In view of the formation of a "Cadastre of Values" in place of the "Income Cadastre" that has always characterized the inventory of real estate present on the Italian territory, the Land Agency, Established by Legislative Decree 30 July 1999, n. 300, this tax agency was incorporated into the Tax Revenue Agency (TRA) with the decree-law of 6 July 2012, n. 95 [5] - converted into law no. 135 [134].

Furthermore, TRA has taken over the management of the Observatory of the Italian Real Estate Market (OIREM), an information system that allows the consultation of data on real estate prices (prices and rents per unit of surface area) throughout the country.

The OIREM data are aggregated by:

- $\quad$ Microzones: B, C, D, E, R;

- Typology: Civil dwellings, Economic dwellings, Boxes, Industrial warehouses, Typical warehouses, Laboratories, Warehouses, Shops, Offices, Structured offices, Villas and cottages;

Other information concern:

- State of conservation 
- Unit prices and rents;

- Minimum, average and maximum quotations returned with reference to the normal or excellent state of maintenance.

The OIREM microzones of the Province of Enna are now 109.

The real estate values have been provided since 2001 every six months for each microzone, by functional type and by state of conservation.

The mapping of OIREM real estate values in the province of Enna was carried out with two levels of aggregation, the first by municipalities, the second by microzones, and in two directions, diachronic and synchronic.

In Figure 4, the map of the retail real estate values of the municipalities is shown as an example. The graphs display the proportions between the extensions of the different microzones with reference to the total of the municipal area. The municipalities of Valguarnera, Catenanuova and Barrafranca have a higher ratio due to the small municipal land. In particular, Barrafranca has the lowest degree of urbanization due to the large municipal land area, which is approximately five times as much as the average; this indicates a much more consistent development of the territory compared to the other two municipalities.
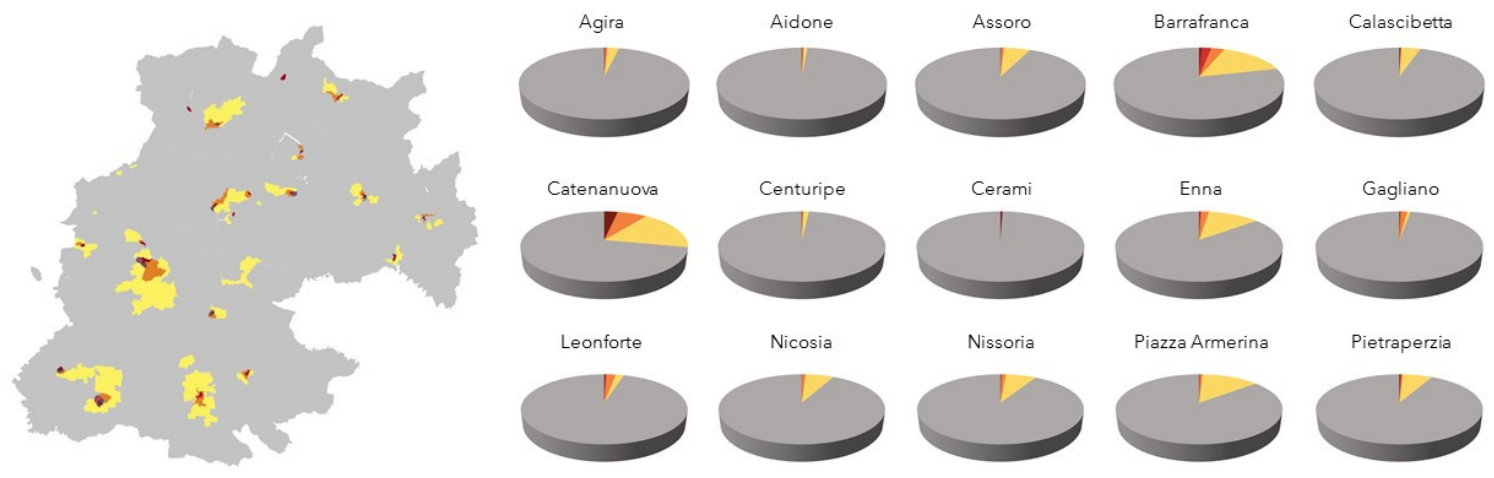

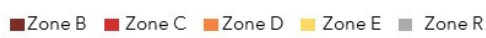
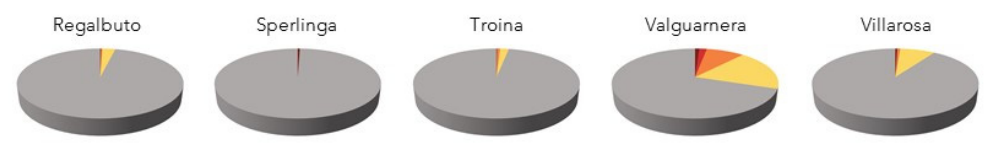

Figure 4. OIREM Micro-zone classification, and distribution of the urbanization of the municipality degree. An OMI zone is a territorial portion that reflects a homogeneous sector of the local housing market: B central, C semi-central, D peripheral, E suburban, R rural. The pie charts show the percentages of the OIREM Micro-zone in the municipal areas.

\section{Methods}

From a methodological point of view, this research is an experiment regarding the coordination of the regimes of description, evaluation and interpretation of territorial information units of different types and at different scales. The principle that justifies and addresses this experiment is the essence of value and, more specifically, the axiological direction implicit in the concept of territorial imbalance, in particular of socio-economic disadvantage, seen not so much from the point of view of the articulation of social subsystems, but rather from the point of view of local communities, and therefore of the urban identities that make up the network of cities in a territory identified from a geographical, administrative and anthropic point of view.

The cognitive functions of description, evaluation and interpretation involved in this process were selected based on 1 . the explanatory possibilities of the model, 2 . the intermediate objectives and 3. the ultimate aims of a territorial evaluation aimed at the perspective of reducing territorial disadvantage.

The model has the form of a dendrogram, a hierarchical model that aggregates around a limited number of general terms of value (interpretative layer), a multiplicity of attributes 
specified by sets of indicators (evaluation layer) and indices, or elementary relationships, internally coherent and externally heterogeneous (descriptive layer) (Figure 5).

This structure allows firstly the placement of a single fragment of information bearing value (meaning) in an unambiguous way, and secondly to associate it with a measure of relative importance with respect to all the others, according to its significance in the overall equilibrium of the descriptive, evaluative and interpretative statement.

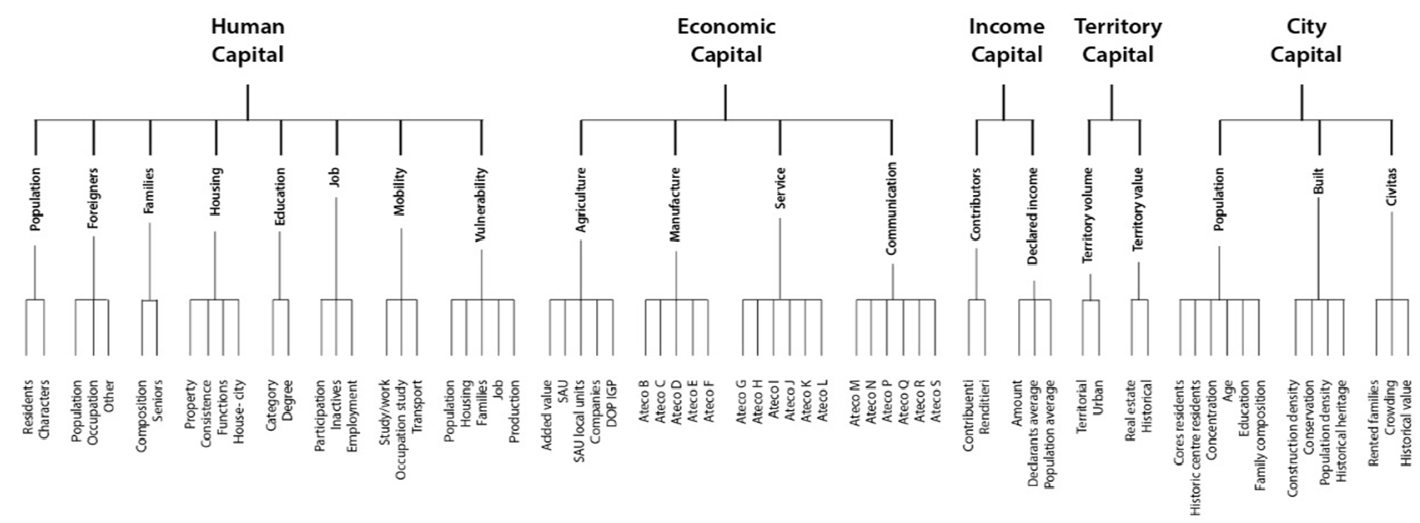

Figure 5. The dendrogram for the description, valuation and interpretation of the life quality within the territorial-urban relational space of the Province of Enna.

The large number of these elementary units of information coming from the official sources, in the absence of such a structure, does not allow decisions to be made in the process of protection and enhancement of the structural components of the territory, such as the socio-economic drivers based on which wealth is created and consolidated in fixed social capital [135].

With the aim of investigating the relationships between the "city effect" and the territorial context-both referring to the socio-economic category of capital [136] — a descriptive model organized on two different levels was created, aggregating the elementary indices in two ways:

- The level of "raw data", i.e., the measures of each phenomenon in itself ordered by groups;

- The level of "information", connecting the elementary measures to the value of the territorial capital based on the form to which they refer.

The vertical crossing of this hierarchical structure [137]:

- From top to bottom-through a process of progressive disaggregation of general forms of capital in terms of particular value-generates an orderly knowledge and places the detailed information term in a coherent taxonomy;

- From bottom to top, progressively turning indices into evaluations and aggregating [138] them into scores which step by step become more meaningful. The descriptive model turns data into information.

- Aggregation by groups does not identify any relationship between the indices other than by nature (population, work, housing, income, real estate values); these indices, taken individually, have a quantitative significance at a low informative level. Many of them use others of the same group and therefore not all of them are independent from each other; consequently, the significance of their simple aggregation by weighted averages could be affected by the "weight" they assume, as they are also indirectly involved in the formation of other indices.

The data used for the subsequent evaluation of the City system in the Enna area have different forms, such as:

- The nature of the data, and therefore the contents of the measures;

- The unit of measurement; 
- $\quad$ The reference, i.e., if it concerns:

- $\quad$ "stocks", i.e., indices in a broad sense, i.e., absolute magnitudes (territorial surface, resident population, number of employees, total income);

- "ratios", i.e., indices in the proper sense, quantities referring to a specific delimitation;

- " "temporal values", i.e., stocks or relationships referring to a specific period;

- "monetary values", different from the previous ones as abstract entities, ultimate consequences of concrete circumstances-the corresponding socio-economic drivers-and furthermore capable in turn of influencing the same premises, therefore of retroacting the causes.

Consequently, their representation can have meaning:

- In itself, if it refers to the same index characterizing the other study units;

- $\quad$ Beyond itself, if referred to other indices, therefore having relevance with respect to the other study units, but by means of a multiplicity of attributes.

The representation of all these measures is proposed by consistency and by indices in view of the subsequent creation of information and therefore of the measurement of values.

In particular, for the representation of the measures having a meaning "beyond oneself", their "alignment" was carried out according to a standard measurement scale, choosing the most effective one from time to time, based on three different normalization procedures, two ones linear, another one a polyline (Figure 6):

- The first one normalizes the different measures in an interval of scores defined between 0 and 2; in this case, 0 refers to the lowest value, and 2 to the highest recorded among the different study units, the municipalities; the defect of this representation consists in not taking into account the effects of the distribution of the measurements among the study units;

- The second, also linear, called "normalization Z" or "standardization", is a procedure "which leads a random variable distributed according to a mean $\mu$ and variance $\sigma^{2}$, to a random variable with a "standard" distribution, i.e., a mean zero and variance equal to 1 ". Consequently, the minimum and maximum values, respectively negative and positive, are not fixed as in the previous case, but only the average one (0);

- The third normalizes the different measures in an interval of scores defined in this case, as in the first one, defined between 0 and 2, but according to a polylinear relation, according to which the score varies within intervals defined by five thresholds referred case by case to the values of the indices recorded for all municipalities:

a. $\quad 0.0$ is associated with the minimum value;

b. $\quad 0.5$ is associated with the value of the first quartile;

c. $\quad 1.0$ is associated with the value of the second quartile (median);

d. $\quad 1.5$ is associated with the value of the third quartile;

e. 2.0 is associated with the maximum value.

a

$$
\begin{gathered}
\text { Standardisation } \\
y_{0-0,5}=0,5 \frac{\left(x-x_{\min }\right)}{\left(x_{q l 1}-x_{\min }\right)} \\
y_{0,5-1}=0,5 \frac{\left(x-x_{q l 1}\right)}{\left(x_{q l 2}-x_{q l 1}\right)}+0,5 \\
y_{1-1,5}=0,5 \frac{\left(x-x_{q l 2}\right)}{\left(x_{q l 3}-x_{q l 2}\right)}+1 \\
y_{1,5-2}=0,5 \frac{\left(x-x_{q l 3}\right)}{\left(x_{\max }-x_{q l 3}\right)}+1,5
\end{gathered}
$$

\section{b}

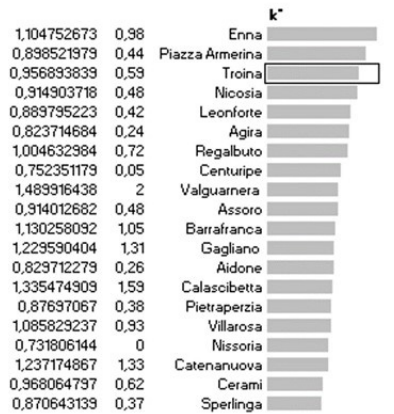

C

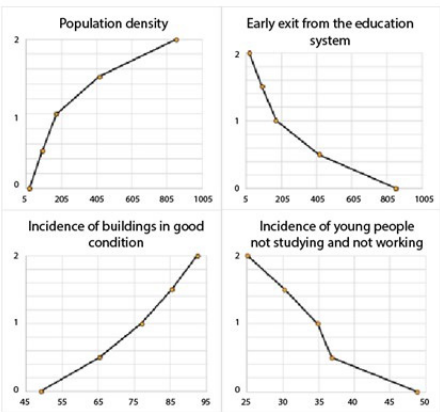

Figure 6. Sample of polylinear standardization: (a) standardization formulas; (b) the ranking of municipalities based on $\mathrm{k}^{*}$; (c) indicators normalized according to the standardization formulas. 
Finally, depending on its uses, normalization can be applied by orienting the polarity or not, thus accounting for the positive or negative relationship between the variation of the index and that of the score. The orientation of polarities involves the sphere of value judgement, which does not concern the application of statistical functions.

\subsection{Cardinal Approach}

The affirmation of the status of values in more complex decision-making activities, such as those that support planning [139] (Kahn, 2012), and in a more general sense the project, has extended the scope of knowledge of utility to hope for values and therefore from the Multi Attribute Utility Theory (MAUT) to the Multi Attribute Value Theory (MAVT) [140].

The MAVT provides methods to structure and analyse decision problems by means of "decision trees" (dendrograms), and to elicit the relative importance of the criteria in this structure.

In an attribute tree, the overall objective is hierarchically divided into underlying subobjectives (called criteria) and lower-level measurable attributes, also called "leaf criteria".

An alternative $x$ is evaluated from the point of view of each attribute $i$, by means of a function of value $v_{i}(x)$. In case of mutual independence of preferences between attributes, it is possible to proceed with a standard additive aggregation. Therefore, the overall value of an alternative is given by the sum of the products of all attributes for the relative weights [141]:

$$
V(x)=\sum_{i=1}^{n} w_{i} v_{i}(x)
$$

where $n$ is the number of attributes, $w_{i}$ is the weight of the attribute $i$ and $v_{i}(x)$ is the value function for the single attribute that reflects the performance of the alternative $x$ with respect to the attribute $i$.

The sum of the weights is equal to 1 and the score is normalized between a minimum value of 0 and a maximum value of 2 .

Weights measure the relative importance of each of the attributes compared to the others [142].

The MAVT can be used to form preference orders between alternative actions in choice problems involving a finite and discrete set of alternative actions to be evaluated basing on conflicting objectives. The model, in fact, assigns to each alternative a number, $V(x)$, obtained as explained above.

The MAVT can use quantitative and qualitative data; if quantitative data are not available, it is possible to resort to judgments by experts.

Since the MAVT aggregates the performance of the options from the point of view of the different criteria, to form an overall valuation it can be considered a compensatory type technique [140].

The formation of a MAVT model is divided into the following phases [142]:

- Definition and structuring of the main objectives and associated criteria;

- Identification of alternatives;

- Attribution of scores to each alternative from the point of view of each criterion;

- Modelling of preferences and evaluation of substitution ratios (trade-off): elicitation of the value functions associated with each criterion and attribution of weighting factors; - Ordering of alternatives: an aggregate score is calculated for each alternative.

The value function is the analytical representation of the human judgment on the option considered, starting from the analytical description of the value system of the subjects involved in the decision.

In particular, a value function translates the performance of the alternatives into scores that represent the extent to which a goal is achieved by each option [143]. 
Many approaches have been proposed in the literature to define value functions [144]. In particular, the following techniques have been proposed: direct rating; "curve fitting"; bisection; standard differences; parameter estimation and semantic judgments [141].

As for the weighting factors, the literature proposes different methods, it being unanimously recognized that the meaning and validity of the weight system are crucial to avoid improper use of the MAVT and therefore the procedures for defining them should not be independent from the way of using them.

In the MAVT approach, which is an additive approach, the weights are scalar constants that allow the functions of the marginal value to assume value in the same interval.

Weights, or scalar constants, can be attributed using different techniques, generally belonging to two families: numerical estimation and comparison. The ordinal procedures, direct weighing and swing-weights belong to the first one, while the trade-off technique belongs to the second one [145-147].

According to the original end of this study, which is the axiological mapping [148-154] of the Province of Enna in terms of the aggregate value of territorial capital in its different dimensions of value, the phases of the application of the MAVT are specified as follows:

- Representation of the identities of the main study units, i.e., the municipalities, instead of alternatives;

- Arrangement of the criteria dendrogram, having as root criteria the five forms of capital: Human, Economic, Territorial, Income, City, and as leaf criteria the indices coming from the different sources, connected at the root by their specifications (branches) consistent with the aforementioned forms of capital;

- Attribution of the leaf scores to each territorial unit by means of the polarized polylinear normalization of the indices referring to their variation ranges of these within the municipal territory, by means of comparison with the values of all municipalities of the entire provincial territory;

- Attribution of the weighting factors to the root criteria;

- Calculation of the scores at the level of the root-criteria by aggregation of the leaf-points;

- Calculation of the overall score attributed to each municipality by aggregation of the scores attributed at the level of the root criteria;

- Ordering of the territorial units based on the overall score attributed with the scalar product between the vector of the aggregated scores and the vector of weights: a total score is calculated for each alternative by means of the overall score.

\subsection{Ordinal Approach}

Parallel to the cardinal approach, which is substantially additive and therefore takes into account the distance in terms of the difference in score between different study units from the point of view of each criterion, a procedure based on comparisons between different municipalities based on their place in the ranking was applied. The model counts the number of times an alternative is in first, second, ..., last position by assigning a score inversely proportional to this position itself ( 20 for the first place in the ranking, 1 for the last place) and ordering the alternatives based on this new score.

\section{Application and Results}

\subsection{Urban Network Quality Indices of the Civil Capital}

By means of the analysis by census sections, new indices have been defined, starting from the comparison and aggregation of data and elementary indices, both by Census Section, and subsequently by Municipalities, in order to measure and map the fifth form of capital:- the City-Capital.

- The latter form of Share Capital includes clusters of indices referable to the population (Human Capital), the buildings-the housing complex only (Urban Capital)-, and finally the relationship between these two entities (Civil Capital).

- The Human Capital includes aspects of the entity, concentration and qualification (Age, Education, Composition of families) of the residents, distinguished by: 
- $\quad$ Residents in the Historic Center;

- Residents in Urban Areas;

- $\quad$ Residents in the remaining part of the municipality;

- The Urban Capital, with reference to the size, density, state of conservation, population density and age of:

- Urban nuclei;

- Historic centers;

- $\quad$ The Civil Capital, with reference to the ownership of houses, to the degree of crowding and to the testimonial value, that is, to the degree of preference of location in:

- Urban Areas;

- Historic Centers

- The calculated indices have been listed as follows:

- IV1-Old age index 1 -is the ratio between +65 -years-old and -20years-old residents. IV1 is also calculated for the UA only;

- $\quad$ EM-Average age-is the weighted average of each age group (terms) based on the number of residents (weights), divided by the total number of resident;

- $\quad$ Mf-Average composition of families-is the weighted average of the members $(1,2$, ..., 6 and more) of households (terms) based on the number of families in each section (weights), divided by the number of families of each Census Section;

- $\mathrm{AbOccS} *$-Average occupied dwelling area-is the ratio between the surface area of dwellings occupied by at least one resident and their number;

- $\mathrm{AbOccS \% -Percentage} \mathrm{of} \mathrm{occupied} \mathrm{housing} \mathrm{surface} \mathrm{area;}$

- EdVol-Building volume-is the product of the housing area by $3.2 \mathrm{~m}$ height;

- 2EdVal-Value of the urban landscape-is the index resulting from the aggregation of the third level indicators concerning the building types (in this case, traditional building types are valued in comparison to contemporary ones); number of floors of the buildings (a higher weight is associated with one storey buildings); building dating (the number of buildings constructed prior to 1960 is valued);

- EdDens-Building density - is the building volume divided by the surface of the Census Section;

- $\quad$ EdData $<1945 \%$-is the percentage of residential buildings prior to 1945 ;

- $\quad \mathrm{P} * \mathrm{CS}$-Population/historic center: Testimonial value, which is the product of residents by the percentage of residential buildings prior to 1945;

- Sezcensval HS - this index measures the degree of preference for the historic center based on the following relations: if the population of the section is high and the number of buildings prior to 1945 is low, it is likely that the majority of residents located in this section prefer new buildings because there are fewer old buildings; if, on the other hand, the population is small and the buildings constructed prior to 1945 are many, it means that in that section the old buildings have been abandoned; if the population is large and the buildings constructed prior to 1945 are many, it means that the population prefers to settle in the historic center; if, on the other hand, the population is small and the buildings constructed before 1945 are a small number as well, it means that residents do not like to settle in areas where contemporary buildings prevail. Ultimately, in both cases, a low index indicates a low preference for the historic center, whereas a high index indicates a high preference for a location in the historic center.

- EdStConsB is the ratio between buildings in a good and excellent state of maintenance and the total building number (edbuono/TOT);

- EdStConsC is the ratio between buildings in a poor and mediocre state of conservation and the total building number (edCAT/TOT);

- $\quad$ Pistr\% is the ratio between residents with a degree and a high school diploma and the total number of residents. 
The indices calculated for the entire Province were mapped on the QGis platform at the level of the Census Sections, and on the scale of the Urban Areas used for the assessments of Human Capital, Urban Capital and Civil Capital.

The simple indices can be variously interpreted according to the size and wealth of cities and the density or stratification of the areas quantities are referred to.

\subsection{The City-Capital: Human and Urban Capital}

The question of the attractiveness of historic centers has highlighted significant correlations between different dimensions of Urban Capital and Human Capital on the scale of the Census Sections of each municipality. The Testimonial Value of each Urban Area was calculated (Figure 7), considered as the willingness to settle in the consolidated urban fabric, then calculated as the ratio between the resident population in the CS and the percentage of buildings erected prior to 1945. By relating the Testimonial Value to indicators that represent the consistency and quality of Human Capital, such as the level of education of the population, the old-age index or the composition of families, some interpretations of the loss of interest in internal areas can be hypothesized, especially for the less accessible historic centers with relevant issues of internal mobility.

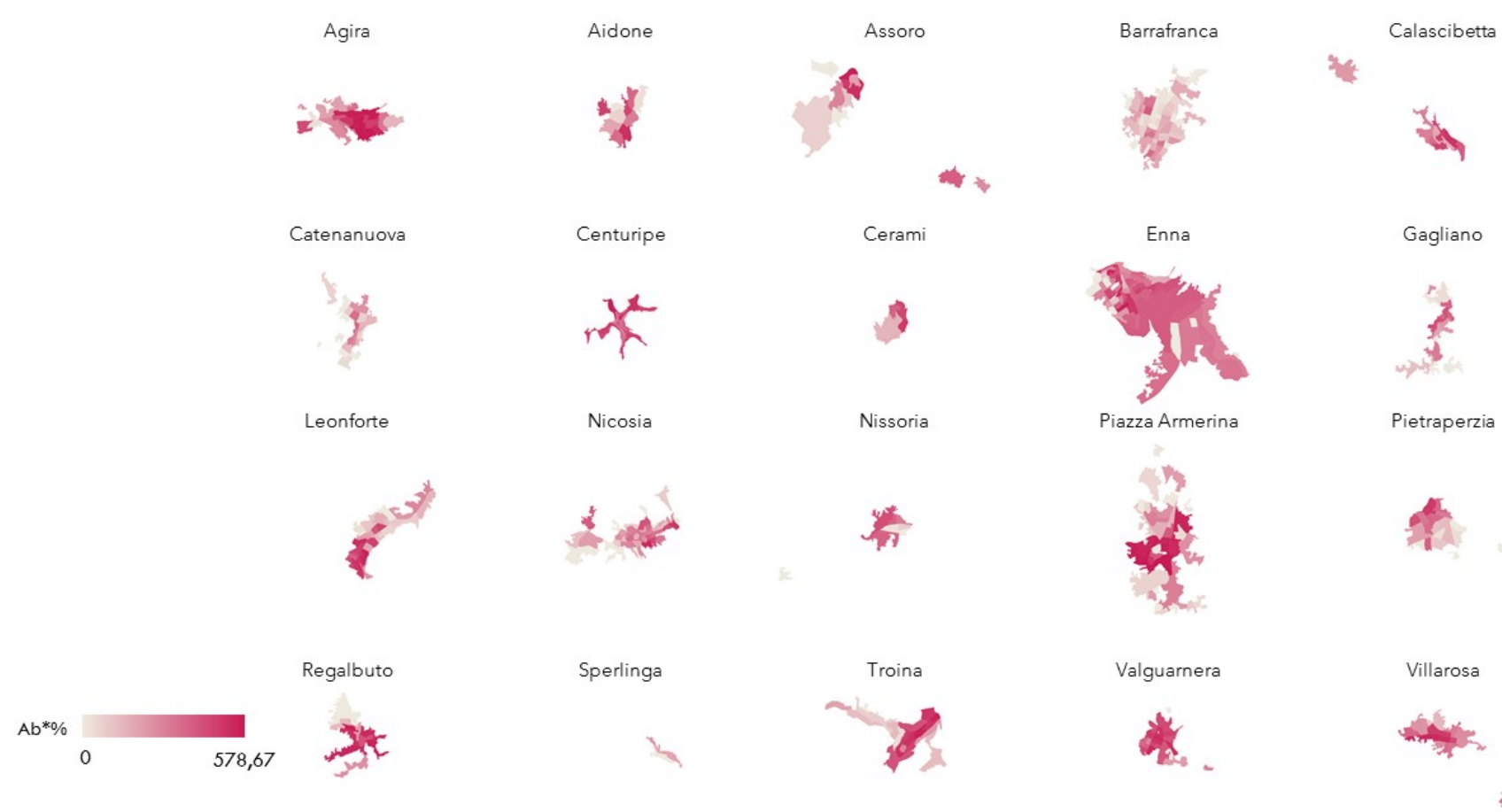

Figure 7. Map of the Testimonial Value on the scale of the Census Sections in the 20 towns of the Enna Province. The Testimonial Value is the product of the number of residents and the percentage of residential buildings erected prior to 1945. This index measures the degree of preference for the historic center. A darker red colour corresponds to a higher value.

Another index, useful for the purpose of describing a significant relationship between aspects of urban capital and human capital, is the ratio between rented households and total population (Figure 8). This index encompasses multiple aspects and certain dualities as regards the relationship between social position and urban profile, concerning level of income, stability of employment, roots in the territory, real estate market values, the state of maintenance of the built heritage which, where better, is more suitable for renting, job opportunities, the range and degree of development of the business fabric, and the panorama of opportunities for individual promotion. Considering that the lighter colour corresponds to a low concentration of rented households, in smaller, less developed municipalities with a lower level of real estate market values, the concentration of rented households depends 
on low income, whereas in the richer and complex towns like Enna, the larger number of rented households depends on the city effect, mostly given by the presence of some significant economic and educational drivers, particularly the University.

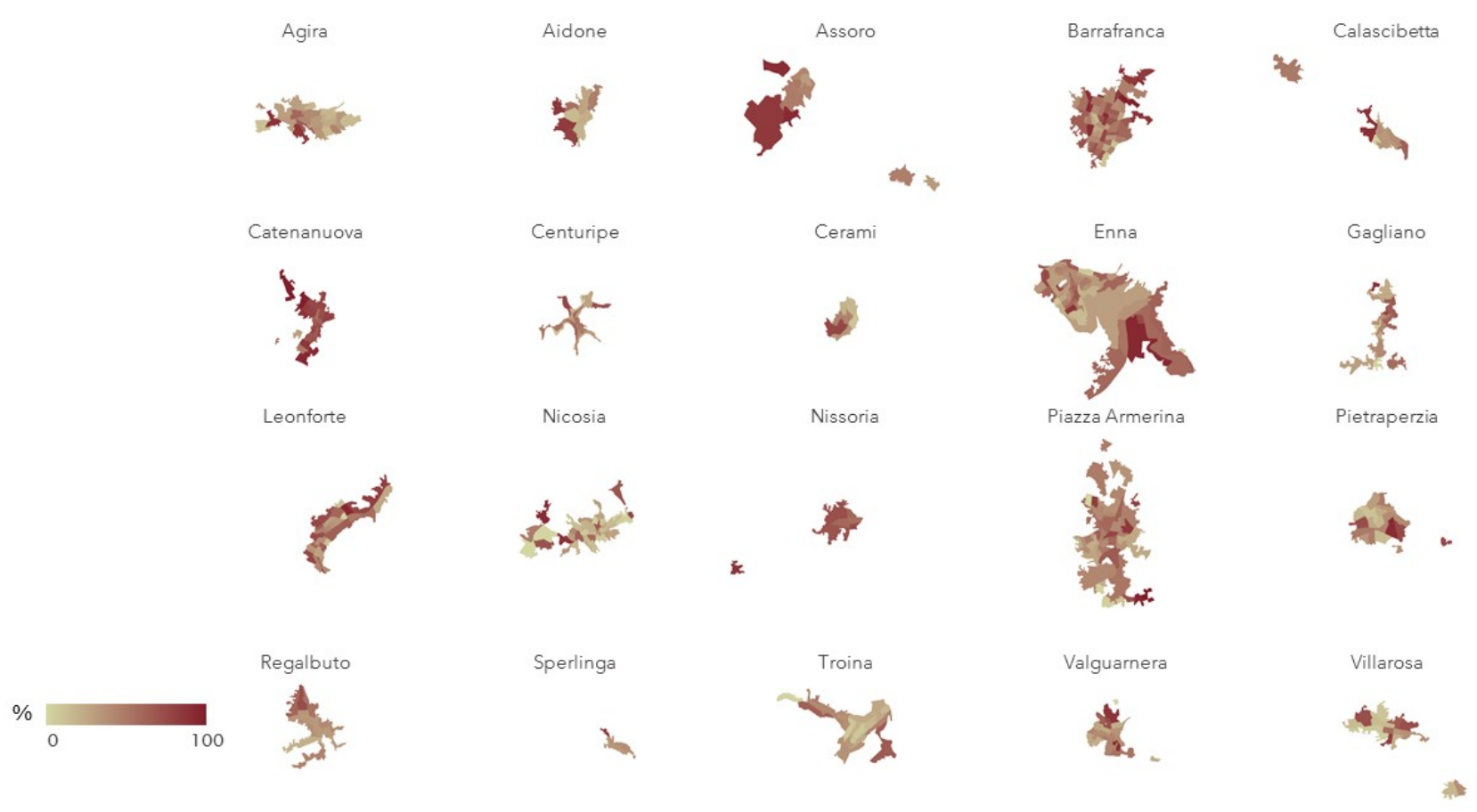

Figure 8. Map of the concentration of the rented households rate on the scale of the Census Sections in the 20 towns of the Enna Province. The darker brown area indicates the maximum value.

Among the many correlations that have been carried out for the purpose of a coherent interpretation of the quality profile of the urban space and the quality of life in the cities of the Enna area, the relationship between the average size of a household in the Urban Areas and the corresponding Testimonial Value is represented in Figure 9, showing a generalized, albeit weak tendency on the part of larger families to settle in less central areas.

The proposed correlations show that the families with a lower average number of members remain in the CS with a higher testimonial value. Conversely, the larger and younger families tend to settle in the most recent peripheral areas.

In general, the graphs that allow the comparison of the municipalities, and are limited to the area of urban nuclei, from the point of view of the relationship between the level of education (indirectly linked to the level of income, data not available at the level of analysis of the census sections) and the tendency of residents to settle in the historic center, provide useful information on the system of location preferences according to the socio-economic status of residents [155-157].

An opposite trend to the previous one, which concerns the reasons why historic centers become attractors of human capital capable of containing the tendency to abandonment, concerns the relationship between the old-age index and the quality of the urban landscape. The latter was calculated with reference to various aspects that characterize historic centers, in particular the presence of older buildings, the reduced standard building size, the building concentration (usually greater in contexts characterized by small buildings) and public spaces on a human scale.

The correlations represented in Figure 10 reveal a generalized tendency of the elderly population to remain in historic centers, and more generally in the most qualified areas characterized by the prevalence of original environmental-urban values, which are at present perceived by younger people as well. 


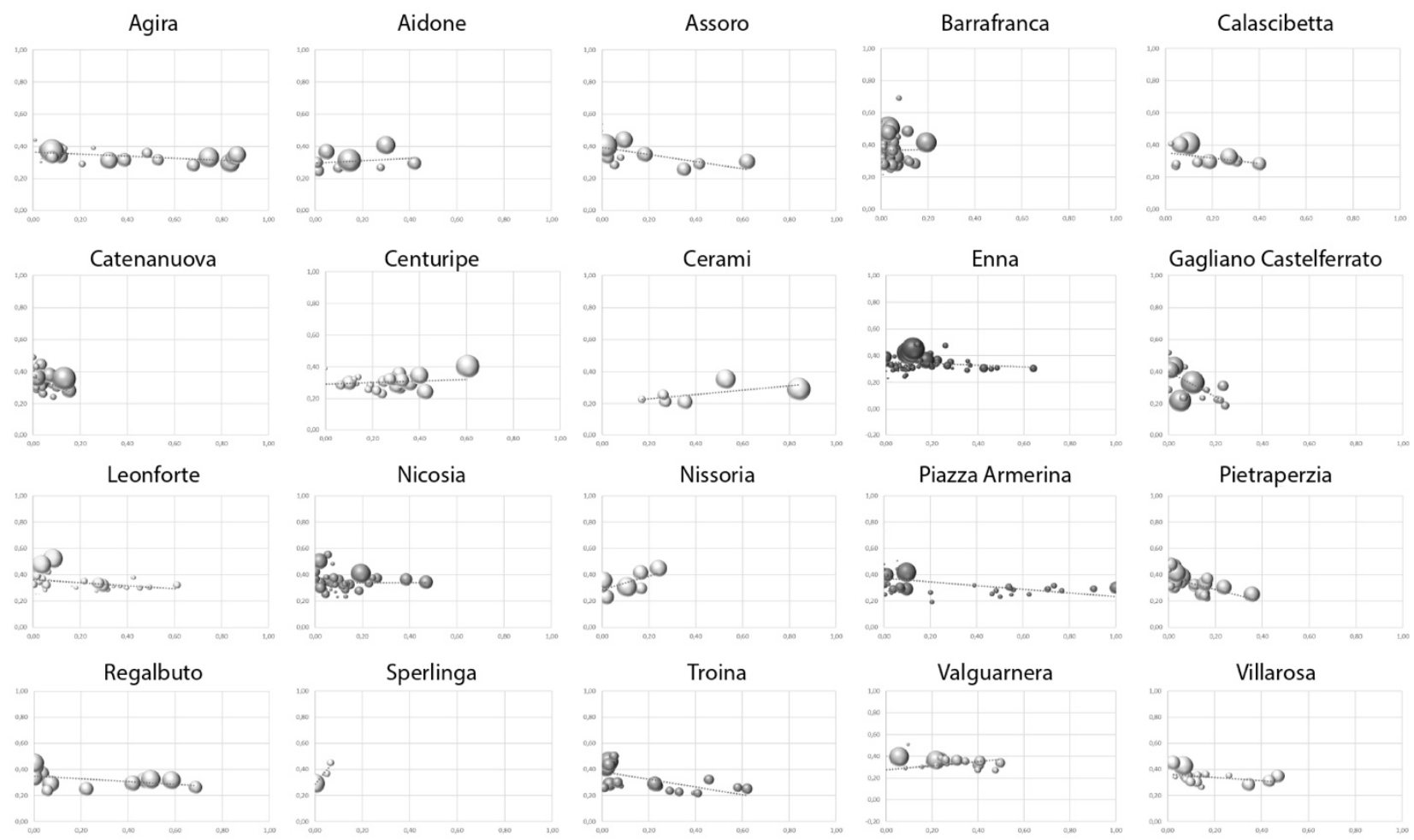

Figure 9. Each graph shows all the Census Sections of the corresponding municipality. On the abscissa is the testimonial value, on the ordinate is the average size of families and the bubble size measures the surface area of the Census Section.

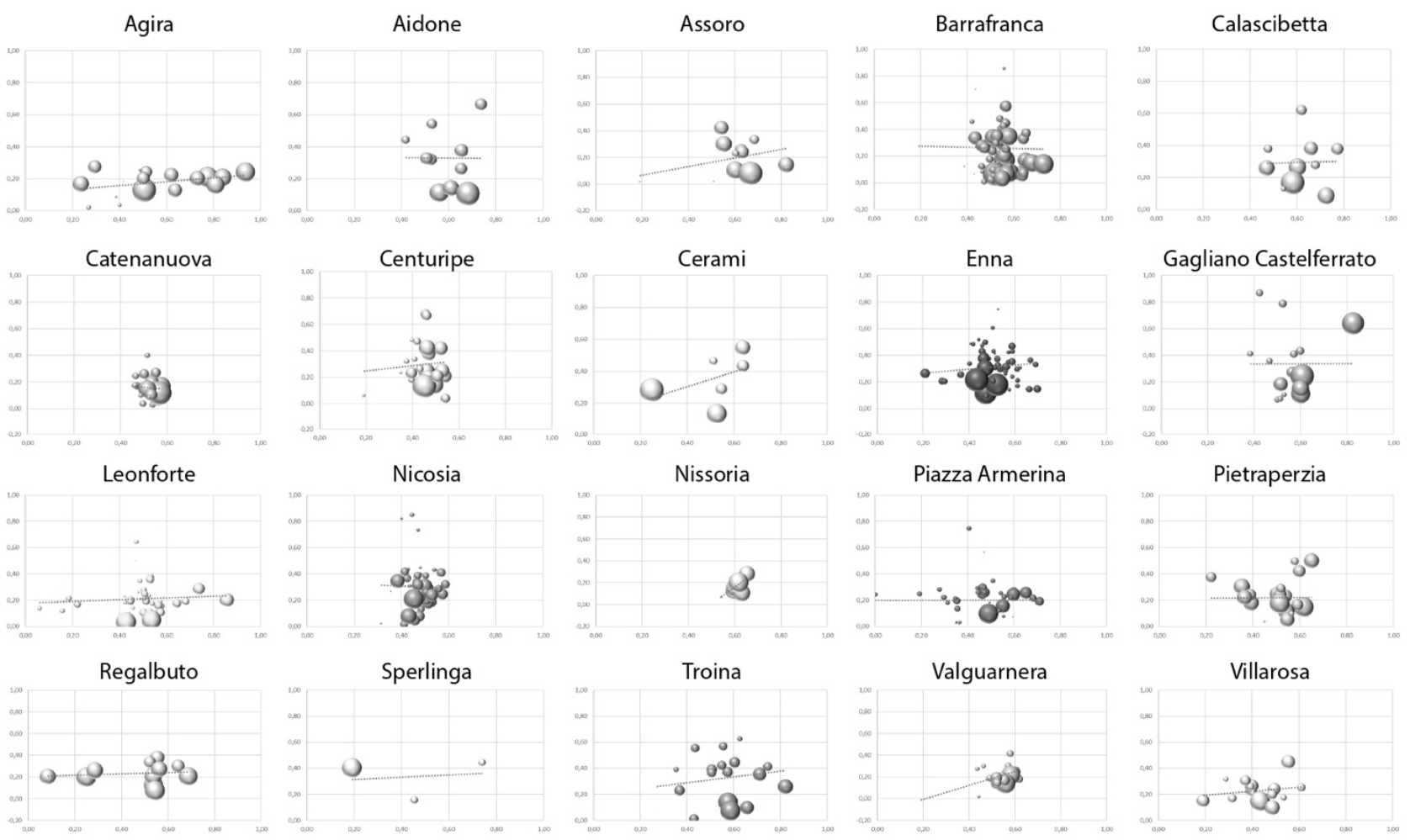

Figure 10. Relation between urban-landscape value (abscissa) and old-age index (ordinate) over the 20 municipalities; the bubble size measures the surface area of the Census Section. 


\subsection{Cities and the Territory}

The hierarchical model summarized by the dendrogram in Figure 5 constitutes the structure of possible ordered comparisons and correlations between specific aspects of the quality of urban space and aggregate values of the different matrices of the quality of living that are expressed on the territorial scale.

The most significant evaluations, obtained at the various levels of the cognitive process, can be compared to verify possible trade-off relationships, convergence and complementarity between the variables. These correlations can cross different forms of capital (correlation between criteria of city capital and economic capital) or different levels of the dendrogram by differently combining correlations between leaf/branch criteria, branch/root criteria and leaf/root criteria.

Two comparisons of great interest for the present purposes concern the relationship between per capita income and testimonial value (Figure 11) and that between Economic Capital and Testimonial Value (Figure 12), which show to what extent the richest local communities express a lower tendency to abandon the old towns.

\section{Per capita Income}

\begin{tabular}{r|} 
Enna \\
Piazza Armerina \\
Nicosia \\
Troina \\
Calascibetta \\
Leonforte \\
Gagliano \\
Agira \\
Villarosa \\
Regalbuto \\
Nissoria \\
Assoro \\
Valguarnera \\
Catenanuova \\
Centuripe \\
Barrafranca \\
Aidone \\
Pietraperzia \\
Sperlinga \\
Cerami \\
\hline
\end{tabular}
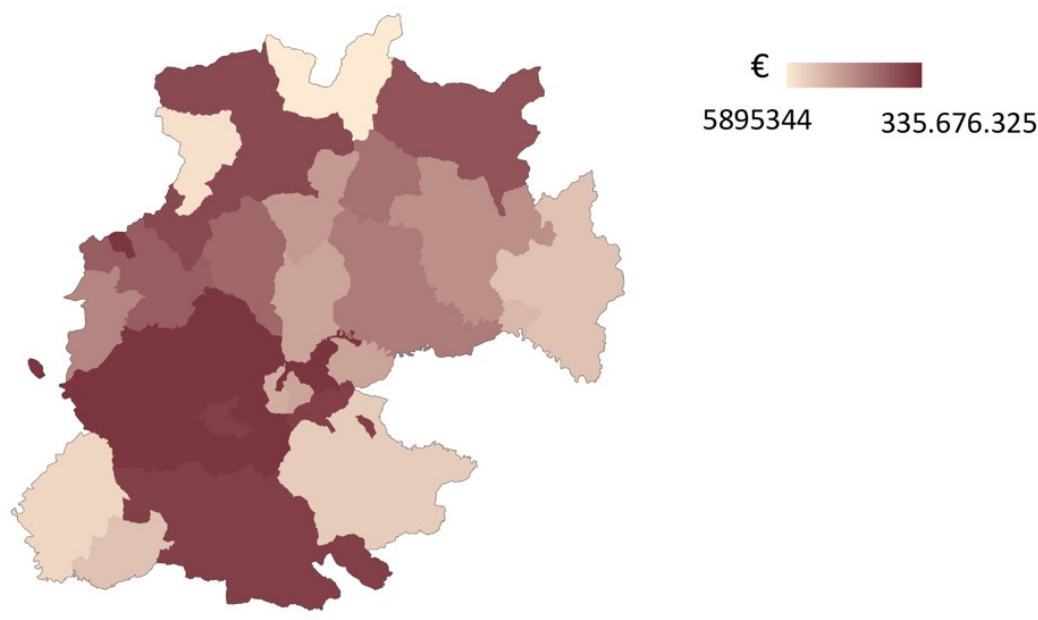

\section{Urban area testimonial value}
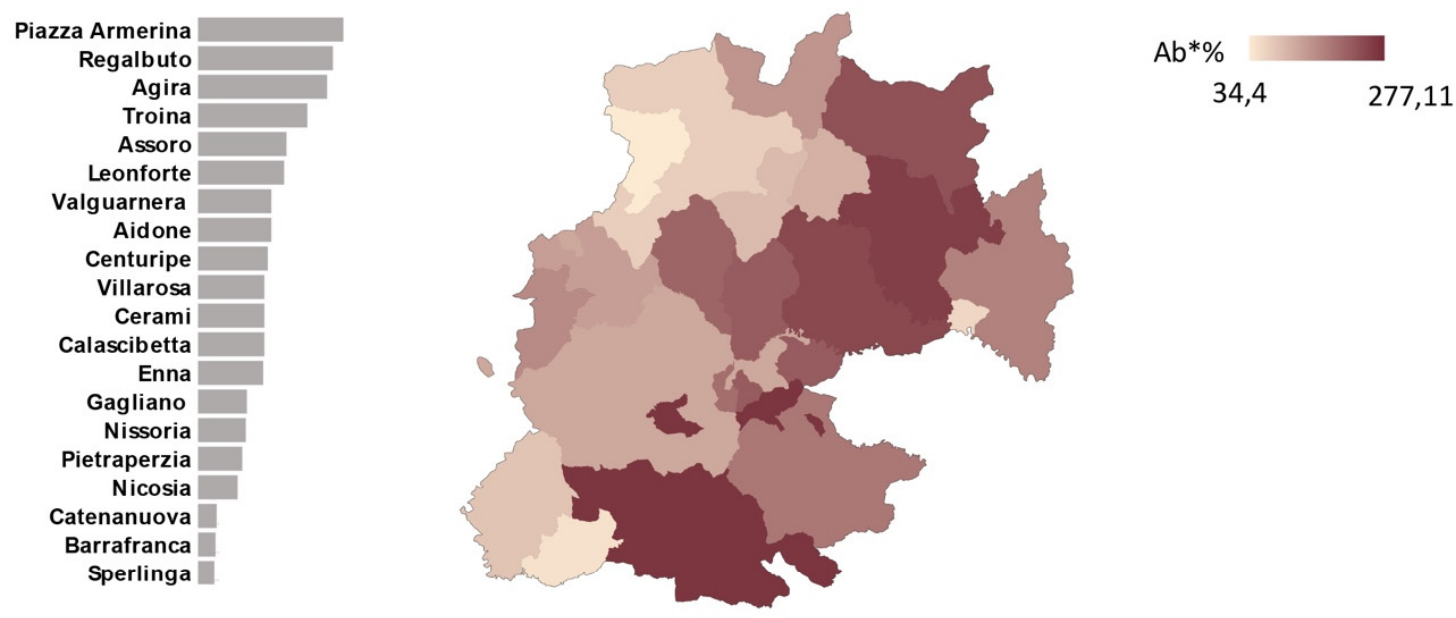

Figure 11. Cont. 

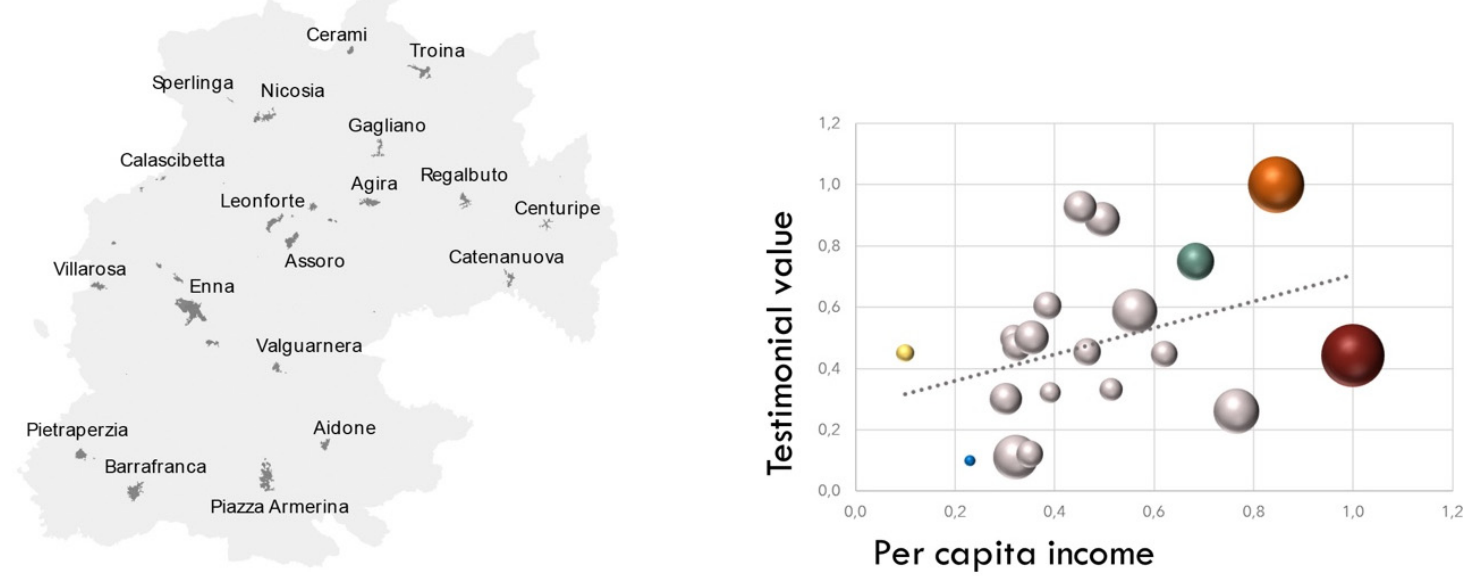

Figure 11. Maps and correlations of Per capita income and Urban area testimonial value in the 20 municipalities (numerical values under the colour ramp).
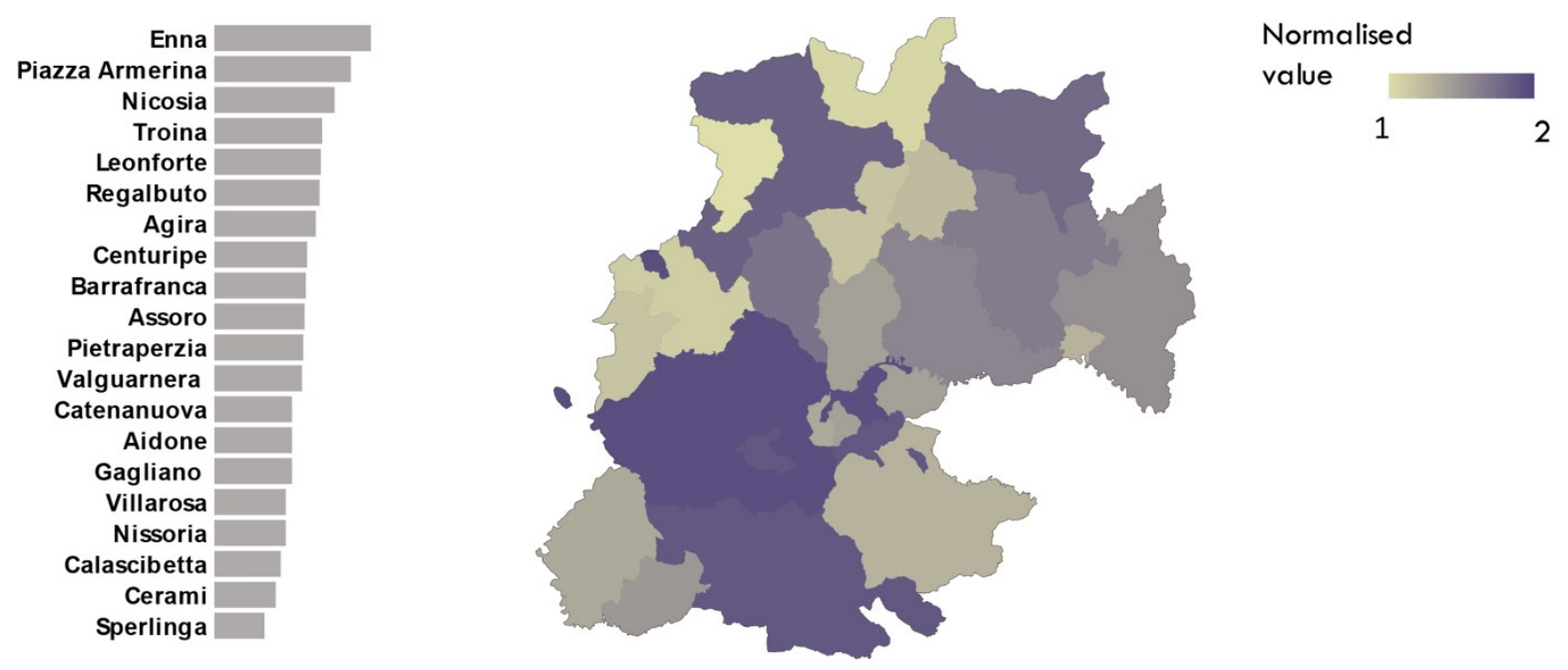

\section{Urban area testimonial value}
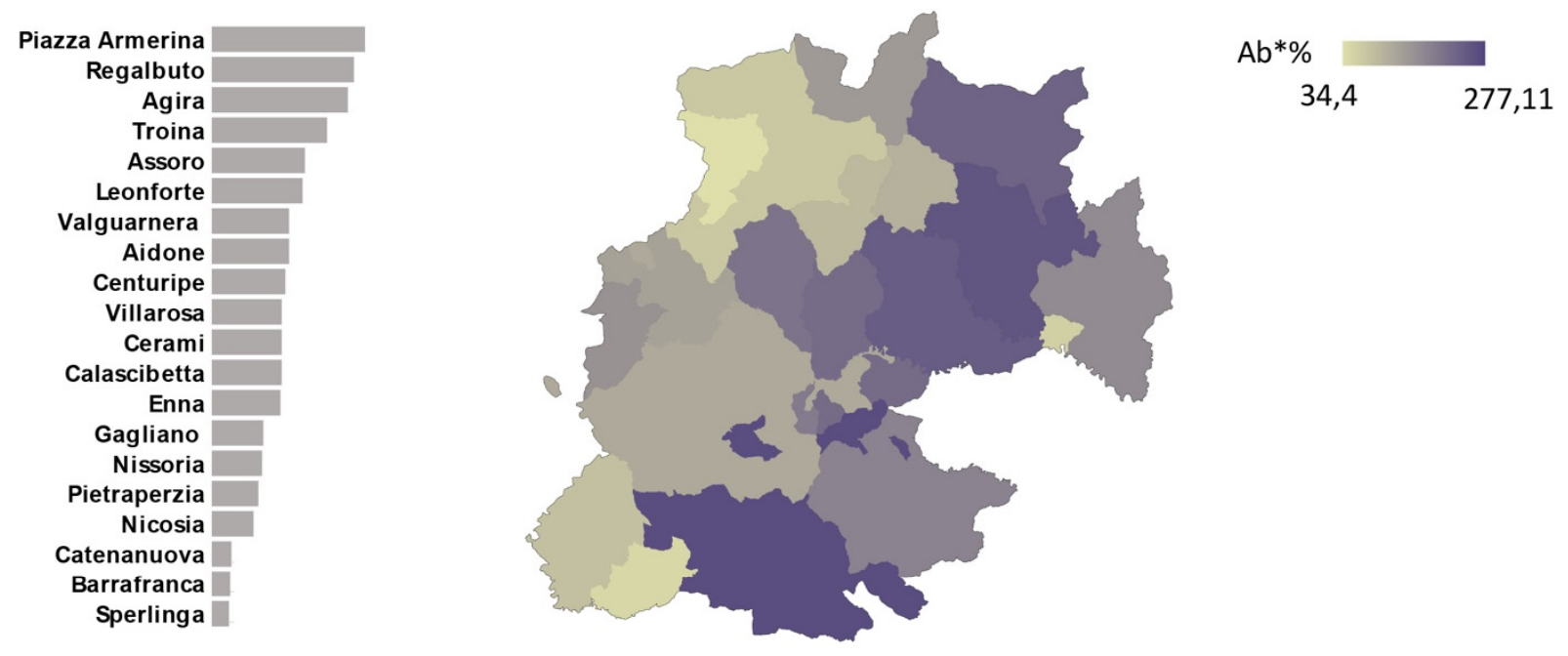

Figure 12. Cont. 

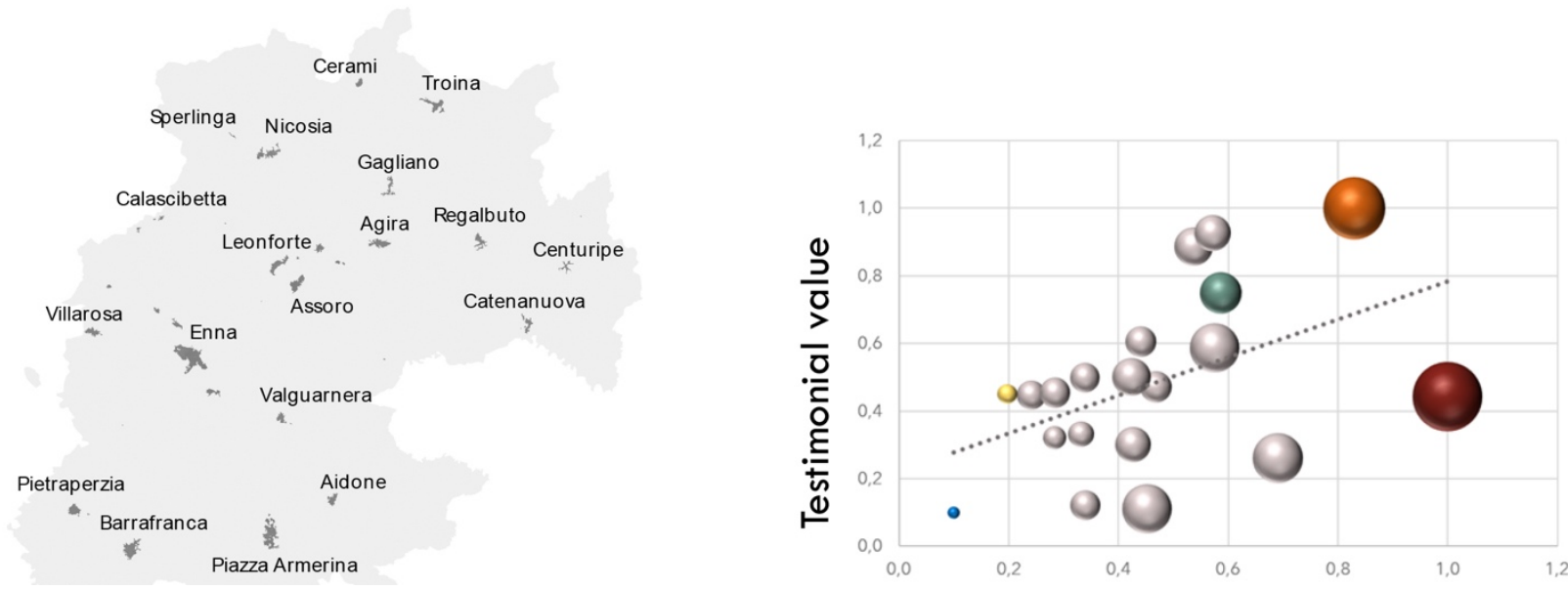

Figure 12. Maps and correlations of Economic capital and Urban area testimonial value over the 20 municipalities (numerical values under the colour ramp).

A further exploration of the relationship between the city network and the provincial territorial dimension was carried out by comparing the density values of the human and urban capital by means of representations at the two levels of detail, namely, the Census Sections and the Municipal administrative units.

As for human density, measured by means of the Building utilization rate (Figure 13), the underutilization of the housing stock in urban areas indicates poor attraction to the urban areas themselves. In reference to the peripheral areas, it indicates either that the new buildings do not meet residential needs or lifestyles, or that they are characterized by very large housing units; in reference to the old towns, it denotes that the general poor state of maintenance and the difficulty of access discourage settling in areas of high testimonial value.

a

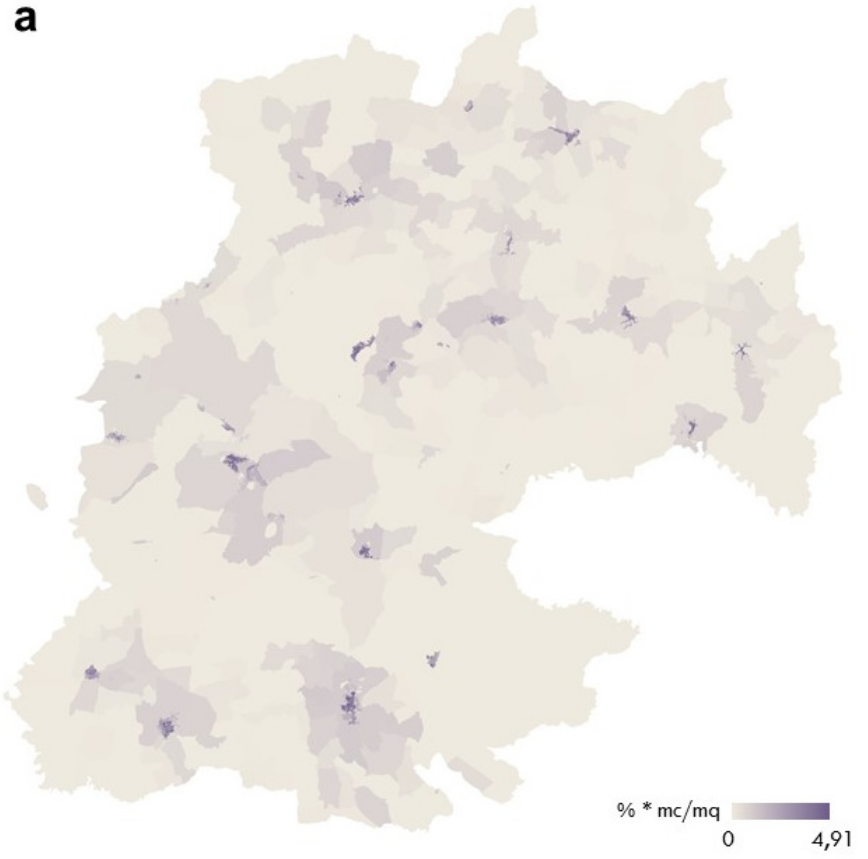

b
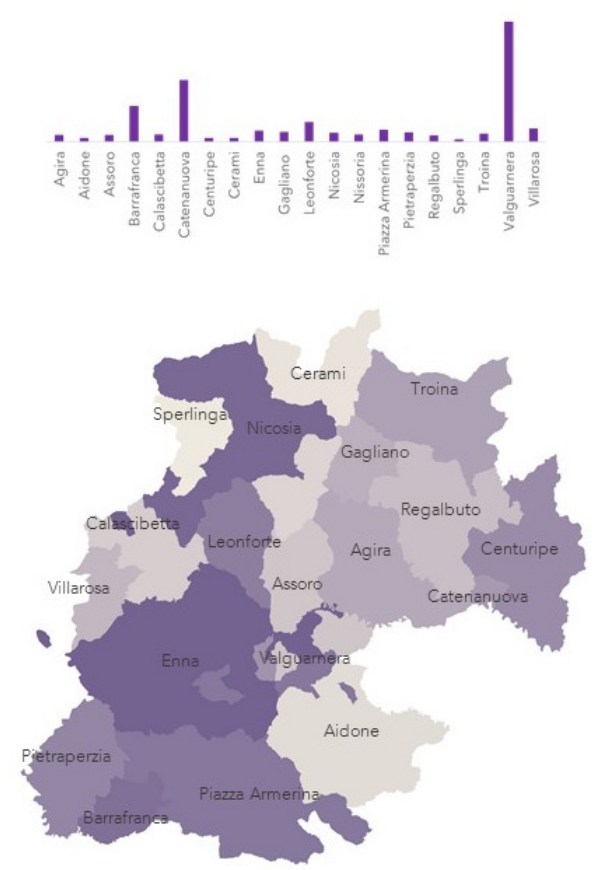

Figure 13. Building utilization rate on the double scale of the Census Sections (a) and Municipalities (b) (numerical values under the colour ramp).

An index complementary to the latter is the building density (Figure 14), which is also mapped at the two levels of detail. The comparison with the previous human 
density indicator supports further in-dept analyses concerning the degree of redundancy of the building stock and the impact of this area of inefficiency in terms of unfairness of the development model on a territorial scale, especially if compared to the other indices and criteria.

a

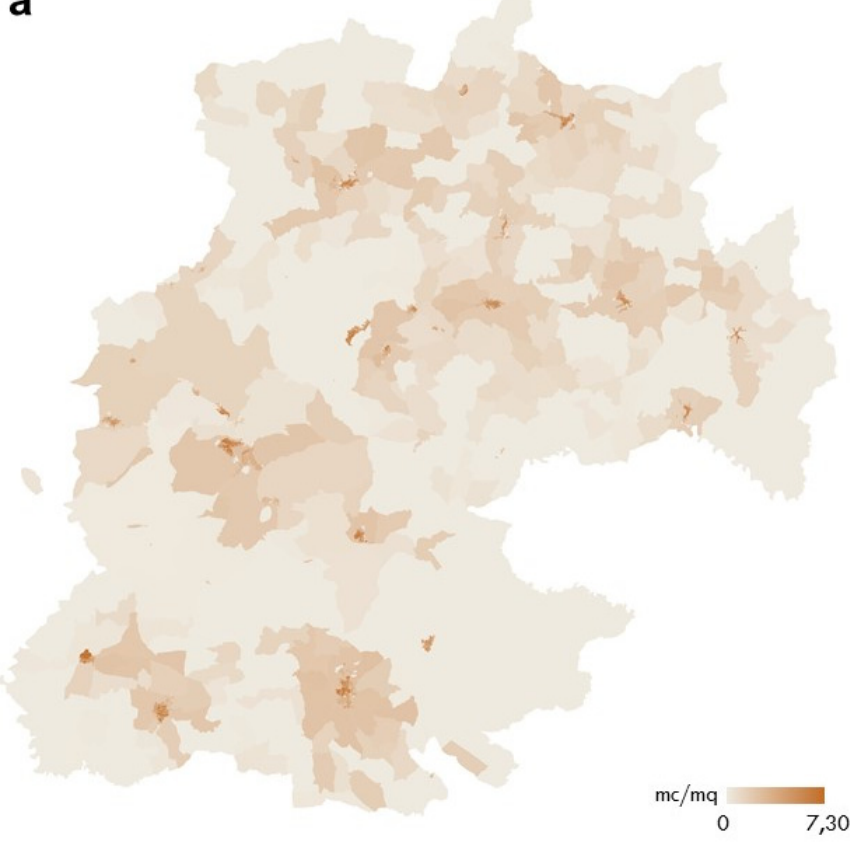

b
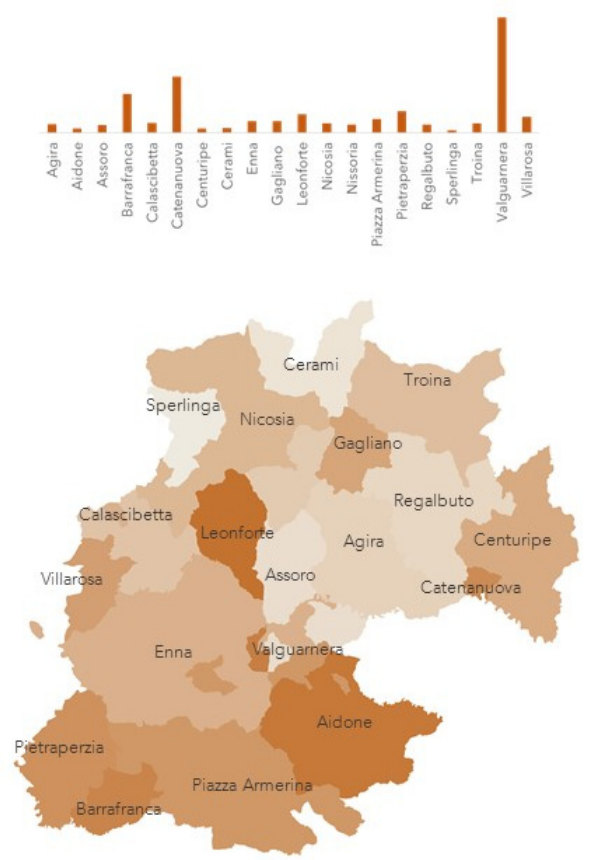

Figure 14. Building density index on the double scale of the Census Sections (a) and Municipalities (b) (numerical values under the colour ramp).

\section{Discussion}

This experience has continued a path of studies, research and creation of cognitive and evaluative models, started at the beginning of 2020 with the object of the inter-scalar territorial analysis aimed at the structured knowledge of the territory and the cities through a critical approach coordinated in the logic of economic evaluation, and therefore based on comparison and oriented by constant reference to the "order of values" [158-178].

In the research process, consequently, the distinction between knowledge, evaluation and planning perspective has dissolved, since the mass of data and information that constituted the raw material of this modelling required itself to be sub-ordered to an end, not only taxonomic or, at least, cognitive, but aimed at supporting the local communities' identity as well as facing the trend towards abandonment.

Compared to previous experiences carried out in this research field, the present one overturned the perspective, initially centripetal, i.e., from territory to city, making it centrifugal, i.e., from the network of cities towards the territory. Therefore, if earlier on the territory was intended as a semantic field around a still nebulous thematic framework, now the clarity of the issue of examining the "urban dimension" of the inner land areas, usually so far from the metropolitan lifestyle, identifies the city network of a "territorial koine" as the whole support for the re-identification of the underdeveloped territories [179-181].

The way in which this research was intended to structure the knowledge of this territory is based on the reduction of territorial and economic information into significant units selected, compared and connected to multiply the original information base [182-189].

The differentiated availability of data that in this experience have been coordinated enriching the explanatory capacity of the model created and extended, has in several cases highlighted some limits and criticalities related to the coherence of surveys and their tabular reduction (creation of integrated databases), as well as the limit of the graphical render- 
ing, which is sometimes ineffective in rendering small-scale phenomena with extended study units.

The ultimate aim of supporting land planning by defining some correlations between the main strategic variables involved different layers of the analysis, thus crossing leaf, branch and root criteria as dependent and/or independent variables.

Some limitations of this analysis concerned the aggregation degree of the branch criteria and above all of the root criteria, due to the valuation pattern chosen (Multi Attribute Valuation Theory), which is of the additive type. Therefore, some significant variables may not have been considered adequately.

Nonetheless, the knowledge of the most relevant aspects of the social, economic and territorial situation of the Enna province allowed us to select the most likely correlations, thus reducing the effects of the compensation of opposite scores that could invalidate the significance of influent characteristics of some territorial units.

To improve the scientific soundness of this early research, mostly intended to create a valuative taxonomy of the territorial information, a further future study will involve the application of the Principal Component Analysis so as to aggregate and then synthesize the most relevant variables by eliminating the redundant ones.

A further novelty of this research was the use of the Geographic Information System, which in future insights and extensions will able to overcome the aforementioned limits with the "spatial join" functions to filter and aggregate information [190-199] and network analyses to add to the official survey aspects related to accessibility; the latter, in this case, is an issue of great impact on territorial relations, in the field of real estate values and for the measurement of the criticalities affecting a less accessible town [200].

\section{Conclusions}

This study was motivated by the search for a coordination between evidence and decisions in the field of urban planning.

From this perspective-in the specific disciplinary field of economic-estimative evaluation-this research continues the commitment to create tools to support the motivations, methods and measurements of the harmony between preservation and transformation of the inner areas.

The contents of these studies are stratified in the accumulation of values of the existing features-natural and artificial—which are running the risk of being overwhelmed by forms of development that are indifferent and often superimposed on them.

This type of study, therefore, has purely argumentative purposes that encounter and address the complexity of territorial systems and the difficulty of representing them in the abstract, in the face of a growing interest in the concreteness of the issues of territorial imbalance, vulnerability, impoverishment and abandonment [201-203].

From this perspective, Figure 15 represents in two complementary radar graphs the comparative synopsis of the performances of these urban and territorial systems; on the left are the 11 most populous ones, while on the right are the 9 least populated ones. This type of comparison does not provide any detailed information, nor does it describe or easily quantify the measure of the territorial, economic, or urban performance of the municipalities, but it gives an effective overview of the positioning of each municipality in a structured semantic field, represented by an impressive database based on which measurements, evaluations and interpretations have been elaborated. 


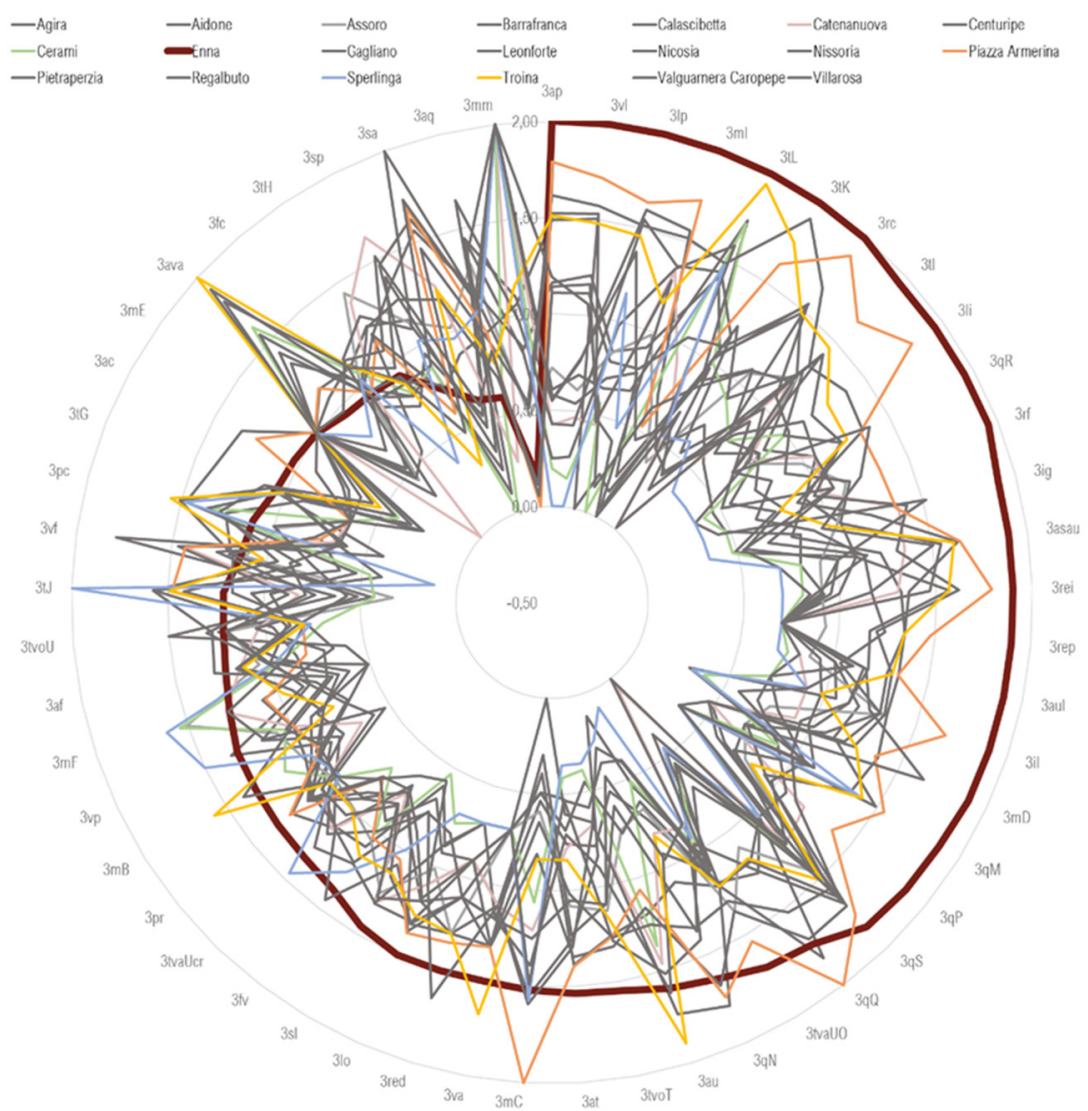

Figure 15. Representation of the structured comparisons between the performances of each of the twenty municipalities.

The organization and internal coherence of the model, its exportability and the possibility of comparing all components to each other by making each component the benchmark of the others have proved to be important functions to develop useful skills for structuring comparative relationships and expanding the spectrum of curiosities.

The basic hypothesis of any analysis structured in an evaluation model is that it can support choice processes between alternative actions and differently characterized (evaluated) actions from the point of view of a multiplicity of criteria representative of different languages and axiological instances. In this case, this hypothesis supports the idea that the municipalities of the province of Enna can confront each other from all points of view and, finally, a multiplicity of rankings can be drawn up.

In particular, each system of weights represents a basic strategy, therefore creating a vision that in turn supports a mission and has an implicit political-decision-making and therefore also a planning value. In this sense, a system of weighting factors attributes greater or lesser importance to the criteria, and within them to the sub-criteria, according to the prevalence of interests and values shared or deemed relevant by the decision maker. The system of weights, however wide the margins of discretion with which they are attributed may be, declares the points of view, the perspectives and the intentions both at the scientific level of the analyst and the evaluator and-even more so-at the political level of the decision maker. Some types of rankings are exemplified below, each with its own meaning and therefore with different outcomes regarding the indication of the areas of the territory or the nodes of the city network, to which greater or lesser attention should be paid in the political decision-making process (Figure 16). 


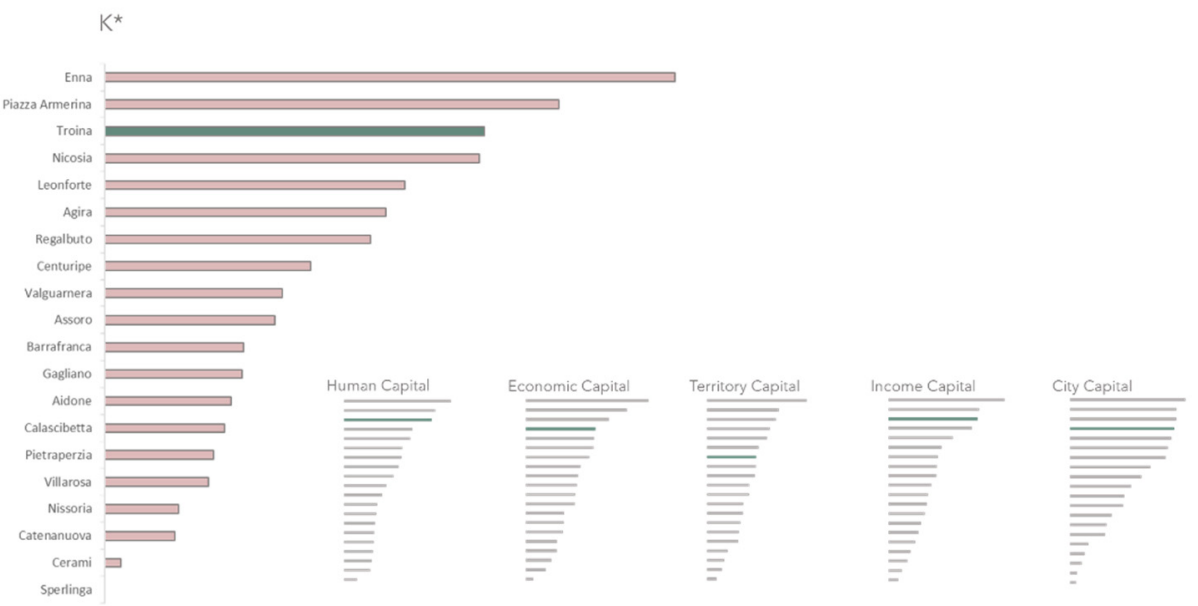

Figure 16. Ranking of the Municipalities basing on the overall normalized score $k^{*}$ and the partial valuations from the points of view of the five forms of social-economic capital asset.

Some conclusive considerations can be aimed at a basic epistemological perspective of this study, and its rooting within an unamendable and resilient matrix, namely, the thermodynamic one.

A socio-territorial system is by definition an open system both in thermodynamic terms (it exchanges matter, energy and information), and in logical terms (it adapts its cognitive apparatus to changes in the environment).

The order level of a system depends on the balance between entropic outflows and neg-entropic incoming flows [204]. Entropy has an origin and a cause:

- The origin is the natural tendency towards long-term thermodynamic equilibrium, which consists in the cancellation of differences, therefore in a condition of nonusability of the energy existing in the system, that means in a condition of molecular disorder;

- The cause is the transformation of the energy existing in the system into mechanical work that produces entropy flows, which accelerate the degradation process that must be compensated for by incoming neg-entropy flows.

The analyses and evaluations so far addressed to the urban territorial systems of the province of Enna have provided results that can be interpreted in the light of this matrix on the basis of which two opposite trends face each other:

- "being form"-in this case with reference to the five forms of capital studied and mapped-concerns organization, that is, neg-entropic or anabolic tension; capital is an economic category capable of self-reproducing and therefore of maintaining constant volume and value, or increasing these through the creation of income flows (neg-entropy), i.e., flows of wealth whose surplus is above costs (for subsistence), accumulate in capital value;

- "being shapeless", that is, not having the necessary tension to trigger dissipative processes capable of creating forms even if at an increasing entropic level.

It is also possible to point out that dissipation is a necessary but not sufficient condition for the creation of form, so if it is true that there cannot be form without dissipation, the opposite is not true, that is, dissipation guarantees order.

By transferring these simple and initial theoretical considerations to the level of the urban form, and by comparing two municipalities characterized by different and opposite combination levels of being form (aggregate value of socio-territorial-urban capital) and being formless (degree of vulnerability), the municipalities of Enna, on the one hand, and Sperlinga, on the other, which occupy the two extremes of the double ranking drawn up with reference to the decreasing values of being form (aggregate capital value), it can be considered that: 
- $\quad$ Sperlinga records the minimum values of being form and minimum values of being shapeless; this apparent contradiction can be interpreted in the light of the minimum entropy production theorem: "For systems close to equilibrium, the production of entropy is minimum at steady state" [205,206];

- Enna, on the other hand, records the maximum values of being form and minimum values of being shapeless; this is consistent with the third law of thermodynamics, which explains the functioning of closed systems, referred to above, and clarifies how to keep the value of capital high in all its forms. It is necessary to trigger and keep alive dissipative processes whose governance-that is, the maintenance structures that allow the transformation of energy to produce mechanical work with a high degree of energy efficiency-guarantees the maintenance of the imbalance between system and environment.

\begin{abstract}
Author Contributions: Conceptualization, L.N. and S.G.; methodology, L.N., S.G. and M.R.T.; validation, L.N. and M.R.T.; formal analysis, M.R.T.; investigation, L.N.; resources, L.N.; data curation, L.N. and S.G.; writing-original draft preparation, L.N., S.G. and M.R.T.; writing-review and editing, L.N., S.G. and M.R.T.; visualization, L.N.; supervision, L.N., S.G. and M.R.T.; project administration, L.N. and M.R.T.; funding acquisition, M.R.T. All authors have read and agreed to the published version of the manuscript.
\end{abstract}

Funding: This work was financed by the University of Catania in a project entitled Architettura a Rischio: Demolire, Recuperare, Restaurare. Il tema della qualità nel progetto sul patrimonioARDeRe, scientific responsible De Medici S., which is part of the general project "Piano della Ricerca Dipartimentale 2020-2022 of the Department of Civil Engineering and Architecture".

Conflicts of Interest: The authors declare no conflict of interest.

\title{
References
}

1. Colavitti, A.M.; Usai, N.; Bonfiglioli, S. Urban Planning in Italy: The Future of Urban General Plan and Governance. Eur. Plan. Stud. 2013, 21, 167-186. [CrossRef]

2. Esposito, P.; Patriarca, F.; Salvati, L. Tertiarization and land use change: The case of Italy. Econ. Model. 2018, 71, 80-86. [CrossRef]

3. Champion, T. Urbanization, Suburbanisation, Counterurbani-Sation and Reurbanisation; Paddison, R., Ed.; Handbook of Urban Studies; Sage: London, UK, 2001; pp. 143-161.

4. Adger, W.N.; Kelly, P.M. Social Vulnerability to Climate Change and the Architecture of Entitlements. Mitig. Adapt. Strat. Glob. Chang. 1999, 4, 253-266. [CrossRef]

5. Eakin, H.; Luers, A.L. Assessing the Vulnerability of Social-Environmental Systems. Annu. Rev. Environ. Resour. 2006, 31, 365-394. [CrossRef]

6. Didkovskyi, O.; Azzone, G.; Menafoglio, A.; Secchi, P. Social and material vulnerability in the face of seismic hazard: An analysis of the Italian case. J. R. Stat. Soc. Ser. A Stat. Soc. 2021, 184, 1549-1577. [CrossRef]

7. Trovato, M.R.; Giuffrida, S. The Monetary Measurement of Flood Damage and the Valuation of the Proactive Policies in Sicily. Geosciences 2018, 8, 141. [CrossRef]

8. Birkmann, J. Measuring vulnerability to promote disaster resilient societies: Conceptual frameworks and definitions. In Measuring Vulnerability to Natural Hazards: Towards Disaster Resilient Societies; Birkmann, J., Ed.; United Nations University Press: Tokyo, Japan, 2006; pp. 9-54.

9. Chakraborty, L.; Rus, H.; Henstra, D.; Thistlethwaite, J.; Scott, D. A place-based socioeconomic status index: Measuring social vulnerability to flood hazards in the context of environmental justice. Int. J. Disaster Risk Reduct. 2019, 43, 101394. [CrossRef]

10. Frigerio, I.; Carnelli, F.; Cabinio, M.; De Amicis, M. Spatiotemporal Pattern of Social Vulnerability in Italy. Int. J. Disaster Risk Sci. 2018, 9, 249-262. [CrossRef]

11. Naselli, F.; Trovato, M.R.; Castello, G. An Evaluation Model for the Actions in Supporting of the Environmental and Landscaping Rehabilitation of the Pasquasia's Site Mining (EN). In Computational Science and Its Applications-ICCSA 2014; Lecture Notes in Computer Science Book Series; Murgante, B., Misra, S., Rocha, A.M.A.C., Torre, C.M., Rocha, J.G., Falcão, M.I., Taniar, D., Apduhan, B.O., Gervasi, O., Eds.; Springer International Publishing: Cham, Switzerland, 2014; pp. 26-41. [CrossRef]

12. Holand, I.S.; Lujala, P. Replicating and Adapting an Index of Social Vulnerability to a New Context: A Comparison Study for Norway. Prof. Geogr. 2013, 65, 312-328. [CrossRef]

13. Trovato, M.R.; Giuffrida, S. The Protection of Territory from the Perspective of the Intergenerational Equity. In Green Energy and Technology; Springer: Berlin/Heidelberg, Germany, 2018; Volume F8, pp. 469-485. [CrossRef] 
14. ISTAT. Index of Social and Material Vulnerability. 2011. Available online: http://ottomilacensus.istat.it/fileadmin/download/ Indice\$ \backslash\$_di\$backslash\$_vulnerabilit\$ $\backslash$ backslash\$\%C3\backslash\$\%A0\$ backslash\$_sociale\$ $\backslash$ backslash\$_e\$ backslash\$_materiale.pdf (accessed on 1 August 2021).

15. Vincent, K. Creating an Index of Social Vulnerability to Climate Change for Africa; Working Paper; Tyndall Center for Climate Change Research: Norwich, UK, 2004; Volume 56, pp. 1-50.

16. Presidenza del Consiglio dei Ministri, Struttura di Missione Casa Italia. Rapporto sulla Promozione della Sicurezza dai Rischi Naturali del Patrimonio Abitativo. 2017. Available online: http://www.casaitalia.governo.it/it/approfondimenti/rapportosulla-promozione-della-sicurezza/ (accessed on 1 August 2021).

17. Barbieri, C.; Canturi, V.; Ciani, F.; Cogliano, V.; Colucci, A.; Cusano, G.; Del Visco, B.; Ienco, E.; Iuliano, N.; Maisto, C.; et al. Architettura e Progetto per la Ricostruzione delle Aree Interne delle Piccole Regioni. Una Strategia di Sviluppo; FrancoAngeli: Milano, Italy, 2019.

18. Lecardane, R.; La Scala, P. Rete di centri minori. Temi e progetti nel territorio di Tindari. In I Centri Minori ... da Problema a Risorsa; Fiore, P., D'Andria, E., Eds.; Franco Angeli: Milano, Italy, 2019; pp. 897-907.

19. Zilli, S.; Dini, F. Il Riordino Territoriale dello Stato. Scenari Italiani 2014. Rapporto Annuale della Società Geografica Italiana Onlus; Società Geografica Italiana Onlus: Rome, Italy, 2015.

20. Giuffrida, S.; Napoli, G.; Trovato, M.R. The urban being between environment and landscape. On the old town as an emerging subject. In Proceedings of the Smart Innovation, Systems and Technologies, 3rd International New Metropolitan Perspectives. Local Knowledge and Innovation Dynamics towards Territory Attractiveness through the Implementation of Hori-zon/Europe2020/Agenda2030, Reggio Calabria, Italy, 22-25 May 2018; pp. 378-386. Available online: https: / /link.springer.com/chapter/10.1007/978-3-319-92102-0_40 (accessed on 2 April 2021).

21. Governo Italiano. Bilancio di Previsione dello Stato per L'anno Finanziario 2021 e Bilancio Pluriennale per il Triennio 2021-2023. (20G00202) (GU Serie Generale n.322 del 30-12-2020—Suppl. Ordinario n. 46). Available online: https://www.gazzettaufficiale.it/atto/serie_generale/caricaDettaglioAtto/originario?atto.dataPubblicazioneGazzetta= 2020-12-30\&atto.codiceRedazionale=20G00202 (accessed on 2 April 2021).

22. United Nations. The 2030 Agenda for Sustainable Development. 2015. Available online: http://sdps.un.org/goals (accessed on 2 April 2021).

23. United Nations. Millennium Development Goals; United Nations: New York, NY, USA, 2015; Available online: https:/ / www.un. org/millenniumgoals/2015_MDG_Report/pdf/MDG\%202015\%20rev\%20(July\%201).pdf (accessed on 2 April 2021).

24. Baratta, A.; Corbi, I.; Corbi, O.; De Andreis, L.; Marchetti, L.; Greco, D.; Petti, L. Heritage Preservation: Challenges and Perspective; FrancoAngeli: Milano, Italy, 2019.

25. Associazione Nazionale Centri Storico Artistici (ANCSA). Centro Ricerche Economiche e Sociali del Mercato dell'Edilizia (Cresme). Centri Storici e Futuro del Paese. Indagine Nazionale sulla Situazione dei Centri Storici; ANCSA: Cresme, Italy, 2017.

26. ISTAT. Rapporto Annuale 2020—La Situazione del Paese. 2020. Available online: https://www.istat.it/it/archivio/244848 (accessed on 1 August 2021).

27. ISTAT. Data Set 8mila Census. Available online: http:/ / ottomilacensus.istat.it/ (accessed on 1 August 2021).

28. ISTAT. Territorial bases and census variables. Available online: https://www.istat.it/it/archivio/104317 (accessed on 1 August 2021)

29. ISTAT. COMIC (COMposite Index Creator). 2013. Available online: https://www.istat.it/it/metodi-e-strumenti/metodi-estrumenti-it/analisi/strumenti-di-analisi/comic (accessed on 1 August 2021).

30. Italian National Statistics Institute (ISTAT). Censimento Della Popolazione e Delle Abitazioni. 2011. Available online: https: / / www.istat.it/it/archivio/censimento+popolazione (accessed on 2 January 2020).

31. Trovato, M.R. A multi-criteria approach to support the retraining plan of the Biancavilla's old town. In Proceedings of the Smart Innovation, Systems and Technologies, 3rd International New Metropolitan Perspectives. Local Knowledge and Innovation Dynamics towards Territory Attractiveness through the Implementation of Hori-zon/Europe2020/Agenda2030, Reggio Calabria, Italy, 22-25 May 2018; Bevilacqua, C., Calabrò, F., Della Spina, L., Eds.; Springer Science and Business Media Deutschland GmbH: Cham, Switzerland, 2019; Volume 101, pp. 434-441. [CrossRef]

32. Borja-Vega, C.; de la Fuente, A. Municipal Vulnerability to Climate Change and Climate-Related Events in Mexico; Policy Research Working Paper 6417; The World Bank Social Development Department Sustainable Development Network: Washington, DC, USA, 2013.

33. Briguglio, L.; Cordina, G.; Farrugia, N.; Vella, S. Economic Vulnerability and Resilience: Concepts and Measurements. Oxf. Dev. Stud. 2009, 37, 229-247. [CrossRef]

34. De Boer, J. The Fragile City: The Epicentre of Extreme Vulnerability; United Nation University Centre for Policy Research, United Nations University: Tokyo, Japan, 2017.

35. Gabrielli, L.; Giuffrida, S.; Trovato, M.R. Real Estate Landscapes and the Historic City: On How Looking Inside the Market. In Proceedings of the Smart Innovation, Systems and Technologies, 3rd International New Metropolitan Perspectives. Local Knowledge and Innovation Dynamics towards Territory Attractiveness through the Implementation of Hori-zon/Europe2020/Agenda2030, Reggio Calabria, Italy, 22-25 May 2018; Bevilacqua, C., Calabrò, F., Della Spina, L., Eds.; Springer Science and Business Media Deutschland GmbH: Cham, Switzerland, 2019; Volume 101, pp. 269-276. [CrossRef] 
36. Barreca, A.; Curto, R.; Rolando, D. Assessing Social and Territorial Vulnerability on Real Estate Submarkets. Buildings 2017, 7, 94. [CrossRef]

37. Leiserowitz, A.A.; Kates, R.W.; Parris, T.M. Sustainability values, attitudes, and behaviors: A review of multinational and global trends. Annu. Rev. Environ. Resour. 2006, 31, 413-444. [CrossRef]

38. Dillard, J.; Dujon, V.; King, M.C. (Eds.) Understanding the Social Dimension of Sustainability; Routledge: New York, NY, USA, 2009.

39. Eizenberg, E.; Jabareen, Y. Social Sustainability: A New Conceptual Framework. Sustainability 2017, 9, 68. [CrossRef]

40. Steiniger, S.; Wagemann, E.; de la Barrera, F.; Molinos-Senante, M.; Villegas, R.; de la Fuente, H.; Vives, A.; Arce, G.; Herrera, J.-C.; Carrasco, J.-A.; et al. Localising urban sustainability indicators: The CEDEUS indicator set, and lessons from an expert-driven process. Cities 2020, 101, 102683. [CrossRef]

41. Trovato, M.R.; Nocera, F.; Giuffrida, S. Life-Cycle Assessment and Monetary Measurements for the Carbon Footprint Reduction of Public Buildings. Sustainability 2020, 12, 3460. [CrossRef]

42. Mascarenhas, A.; Coelho, P.; Subtil, E.; Ramos, T.B. The role of common local indicators in regional sustainability assessment Ecol. Indic. 2010, 10, 646-656. [CrossRef]

43. Pires, S.M.; Fidélis, T. A proposal to explore the role of sustainability indicators in local governance contexts: The case of Palmela, Portugal. Ecol. Indic. 2012, 23, 608-615. [CrossRef]

44. Ramos, T.; Caeiro, S. Meta-performance evaluation of sustainability indicators. Ecol. Indic. 2010, 10, 157-166. [CrossRef]

45. Tanguay, G.A.; Rajaonson, J.; Lefebvre, J.-F.; Lanoie, P. Measuring the sustainability of cities: An analysis of the use of local indicators. Ecol. Indic. 2010, 10, 407-418. [CrossRef]

46. Van Zeijl-Rozema, A.; Martens, P. An adaptive indicator framework for monitoring regional sustainable development: A case study of the INSURE project in Limburg, The Netherlands. Sustain. Sci. Pract. Policy 2010, 6, 6-17. [CrossRef]

47. Costanza, R. Valuing natural capital and ecosystem services toward the goals of efficiency, fairness, and sustainability. Ecosyst. Serv. 2020, 43, 101096. [CrossRef]

48. Trovato, M. An Axiology of Residual Green Urban Areas. Environments 2021, 8, 53. [CrossRef]

49. Navarro, C.J.; Rodríguez-García, M.J. Urban policies as multi-level policy mixes. The comparative urban portfolio analysis to study the strategies of integral urban development initiatives. Cities 2020, 102, 102716. [CrossRef]

50. OECD. Making Decentralisation Work: A Handbook for Policy-Makers; OECD Multilevel Governance Studies; OECD Publishing: Paris, France, 2019. [CrossRef]

51. Liu, W.; Dunford, M.; Song, Z.; Chen, M. Urban-rural integration drives regional economic growth in Chongqing, Western China. Area Dev. Policy 2016, 1, 132-154. [CrossRef]

52. Schintler, L.A.; Kulkarni, R. Big Data for Policy Analysis: The Good, The Bad, and The Ugly. Rev. Policy Res. 2014, 31, 343-348. [CrossRef]

53. Fernández-García, M.; Navarro, C.J.; Gómez-Ramirez, I. Evaluating Territorial Targets of European Integrated Urban Policy. The URBAN and URBANA Initiatives in Spain (1994-2013). Land 2021, 10, 956. [CrossRef]

54. Lawless, P. Can area-based regeneration programmes ever work? Evidence from England's New Deal for Communities Programme. Policy Stud. 2012, 33, 313-328. [CrossRef]

55. Powell, M.; Boyne, G.; Ashworth, R. Towards a geography of people poverty and place poverty. Policy Politics 2001, 29, 243-258. [CrossRef]

56. Spencer, J.H. People, Places, and Policy: A Politically Relevant Framework for Efforts to Reduce Concentrated Poverty. Policy Stud. J. 2004, 32, 545-568. [CrossRef]

57. Blank, R.M. Poverty, Policy, and Place: How Poverty and Policies to Alleviate Poverty Are Shaped by Local Characteristics. Int Reg. Sci. Rev. 2005, 28, 441-464. [CrossRef]

58. Servillo, L.; Atkinson, R.; Russo, A. Territorial attractiveness in EU urban and spatial policy: A critical review and future research agenda. Eur. Urban Reg. Stud. 2011, 19, 349-365. [CrossRef]

59. Napoli, G.; Barbaro, S.; Giuffrida, S.; Trovato, M.R. The European Green Deal: New Challenges for the Economic Feasibility of Energy Retrofit at District Scale. Smart Innov. Syst. Technol. 2020, 178, 1248-1258. [CrossRef]

60. Wong, C. Indicators for Urban and Regional Planning: The Interplay of Policy and Methods; Routledge: Abingdon, UK, 2006. [CrossRef]

61. Andersson, R.; Musterd, S. Area-based policies: A critical appraisal. Tijdschr. Econ. Soc. Geogr. 2005, 96, 377-389. [CrossRef]

62. Holman, N. Incorporating local sustainability indicators into structures of local governance: A review of the literature. Local Environ. 2009, 14, 365-375. [CrossRef]

63. D’Orlando, E. Territori e Potere. Un Nuovo Ruolo per Regioni ed enti Locali? Prolusione all'Inaugurazione del $41^{\circ}$ Anno Accademico 2018/2019 Università degli Studi di Udine. 2018. Available online: https:/ / qui.uniud.it/notizieEventi/ateneo/ inaugurato-il-nuovo-anno-accademico2018-19/territori-e-potere-un-nuovo-ruolo-per-regioni-ed-enti-locali-prolusionedellaprof-ssa-elena-dorlando (accessed on 10 October 2021).

64. Trovato, M.; Micalizzi, P.; Giuffrida, S. Assessment of Landscape Co-Benefits in Natura 2000 Site Management Plans. Sustainability 2021, 13, 5707. [CrossRef]

65. UVAL. A Strategy for Inner Areas in Italy: Definition, Objectives, Tools and Governance; Materiali Uval Series; UVAL: Rome, Italy, 2014.

66. Governo Italiano. Nuove Disposizioni per le Zone Montane. LEGGE 31 Gennaio 1994, n. 9. (G.U. Serie Generale n.32 del 09-02-1994Suppl. Ordinario n. 24); Governo Italiano: Rome, Italy, 1994. 
67. Governo Italiano. Misure per il Sostegno e la Valorizzazione dei Piccoli Comuni, Nonché" Disposizioni per la Riqualificazione e il Recupero dei Centri Storici dei Medesimi Comuni. LEGGE 6 Ottobre 2017, n. 158 (17G00171) (GU Serie Generale n.256 del 02-11-2017); Governo Italiano: Rome, Italy, 2017.

68. Ministero dell'Interno. Definizione dei Parametri per la Determinazione delle Tipologie dei Piccoli Comuni che Possono Beneficiare dei Finanziamenti Previsti dalla Legge 6 Ottobre 2017, n. 158. Decreto 10 Agosto 2020 (20A04583) (GU Serie Generale n.213 del 27-08-2020); Governo Italiano: Rome, Italy, 2017.

69. Hoffman, A.; Camagni, R.P.; Latella, F. Mezzogiorno e Scienze Regionali: L'Analisi e la Programmazione; Franco Angeli Edizioni: Milano, Italy, 1992.

70. Bolton, R. An Economic Interpretation of a 'Sense of Place'; Papers 130; Department of Economics Working Papers; Department of Economics, Williams College: Williamstown, MA, USA, 1989.

71. OECD. OECD Regional Outlook 2019: Leveraging Megatrends for Cities and Rural Areas; OECD Publishing: Paris, France, 2019 [CrossRef]

72. OECD. Regional, Rural and Urban Development. Available online: https://www.oecd.org/regional/ (accessed on 10 October 2021).

73. Hobbs, R.; Higgs, E.; Hall, C.M.; Bridgewater, P.; Chapin, F.S.; Ellis, E.; Ewel, J.J.; Hallett, L.; Harris, J.; Hulvey, K.B.; et al Managing the whole landscape: Historical, hybrid, and novel ecosystems. Front. Ecol. Environ. 2014, 12, 557-564. [CrossRef]

74. Carluccio, M.; Del Regno, R.; Roselli, A. I Borghi Abbandonati dell'Irpinia: Un'Eredità Dimenticata; FrancoAngeli: Milano, Italy, 2019.

75. Teti, V. Il Senso dei Luoghi. Memoria e Vita dei Paesi Abbandonati; Donzelli: Rome, Italy, 2004.

76. OECD. Le Sfide dello Sviluppo Locale e il Ruolo delle Aree Vaste nella Pianificazione Strategica; OECD Trento Centre, Trento. 2018. Available online: www.oecd.org/cfe/leed/2018-Working-Paper-FVG-EN.pdf (accessed on 10 October 2021).

77. Thomson, D.E. Strategic, Geographic Targeting of Housing and Community Development Resources. Urban Aff. Rev. 2008, 43, 629-662. [CrossRef]

78. Rolando, D. Multicriteria decision problem structuring: The strategic choice approach in the context of public projects in Italy. Int J. Multicriteria Decis. Mak. 2015, 5, 4-38. [CrossRef]

79. Albrechts, L.; Balducci, A.; Hillier, J. (Eds.) Situated Practices of Strategic Planning: An International Perspective; Routledge: Abingdon, UK, 2016. [CrossRef]

80. Moccia, F.D. Resistenze alla pianificazione strategica: Una analisi trans-culturale della ricezione ed uso della pianificazione strategica nella pianificazione integrata italiana. In Pianificazione Strategica e Governabilità Ambientale; Archibugi, F., Saturnino, A., Eds.; Alinea Editrice: Firenze, Italy, 2004.

81. Cicerchia, A. Pianificazione Strategica e Ambiente: Teorie, Metodi, Strumenti ed Esperienze Internazionali; Franco Angeli: Milano, Italy, 2000.

82. Archibugi, F. Introduzione alla Pianificazione Strategica in Ambito Pubblico; Alinea Editrice: Firenze, Italy, 2005.

83. Della Spina, L. Strategic Planning and Decision Making: A Case Study for the Integrated Management of Cultural Heritage Assets in Southern Italy. In New Metropolitan Perspectives. NMP 2020. Smart Innovation, Systems and Tecashnologies; Bevilacqua, C., Calabrò, F., Della Spina, L., Eds.; Springer: Cham, Switzerland, 2021; Volume 178, pp. 1116-1130. [CrossRef]

84. La Torre, M.; Semplici, L.; Zapata, J.S. Un Modello di Impact Finance per i Comuni: Il Piano Strategico di Mandato BES-Oriented Corp. Gov. Res. Dev. Stud. 2021, 141-170. [CrossRef]

85. Katz, E.G. Social Capital and Natural Capital: A Comparative Analysis of Land Tenure and Natural Resource Management in Guatemala. Land Econ. 2000, 76, 114. [CrossRef]

86. Coleman, J.S. Social Capital in the Creation of Human Capital; Oxford University Press: Oxford, UK, 2003. [CrossRef]

87. de Hart, J.; Dekker, P. A tale of two cities: Local patterns of social capital. In Generating Social Capital: Civil Society and Institutions in Comparative Perspective; Hooghe, M., Stolle, D., Eds.; Palgrave: New York, NY, USA, 2003; pp. 153-170.

88. Napoli, G.; Giuffrida, S.; Trovato, M.R. Efficiency versus Fairness in the Management of Public Housing Assets in Palermo (Italy). Sustainability 2019, 11, 1199. [CrossRef]

89. Lowndes, V.; Wilson, D.J. Social Capital and Local Governance: Exploring the Institutional Design Variable. Political Stud. 2001, 49, 629-647. [CrossRef]

90. Maloney, W.; Smith, G.; Stoker, G. Social Capital and Urban Governance: Adding a More Contextualized 'Top-down' Per-spective. Political Stud. 2000, 48, 802-882. [CrossRef]

91. Newton, K. Trust, social capital, civil society, and democracy. Int. Political Sci. Rev. 2001, 22, 201-214. [CrossRef]

92. Glaeser, E.L.; Charles Redlick, C. Social Capital and Urban Growth; Working Paper 14374; National Bureau of Economic Research: Cambridge, MA, USA, 2008; Available online: http:/ /www.nber.org/papers/w14374 (accessed on 10 October 2021).

93. Goodwin, N.R. Five Kinds of Capital: Useful Concepts for Sustainable Development. 2003. Available online: http:/ / ageconsearch. umn.edu/bitstream/15595/1/wp030007.pdf (accessed on 10 October 2021).

94. World Bank. Where is the wealth of nations? Measuring Capital for the 21st Century. 2006. Available online: http://siteresources. worldbank.org/INTEEI/214578-1110886258964/20748034/All.pdf (accessed on 10 October 2021).

95. Napoli, G.; Giuffrida, S.; Trovato, M.R. Fair Planning and Affordability Housing in Urban Policy. The Case of Syracuse (Italy). In ICCSA 2016, LNCS 9789; Gervasi, O., Apduhan, B.O., Taniar, D., Torre, C.M., Wang, S., Misra, S., Murgante, B., et al., Eds.; Springer International Publishing: Cham, Switzerland, 2016; Part III, pp. 46-62. [CrossRef] 
96. Camagni, R.; Capello, R. Regional Competitiveness and Territorial Capital: A Conceptual Approach and Empirical Evidence from the European Union. Reg. Stud. 2013, 47, 1383-1402. [CrossRef]

97. Clawson, M. Economic and social conflicts in land use planning. Nat. Resour. J. 1975, 15, 473-489.

98. Sumner, J.; Bird, L.; Smith, H. Carbon Taxes: A Review of Experience and Policy Design Considerations; Technical Report NREL/TP6A2-47312; National Renewable Energy Laboratory: Golden, CO, USA, 2011. Available online: http://www.nrel.gov/docs/fy1 0osti/47312.pdf (accessed on 2 April 2021).

99. Spilimbergo, A.; Ubeda, L. A model of multiple equilibria in geographic labor mobility. J. Dev. Econ. 2004, 73, 107-123. [CrossRef]

100. Winnick, L. Place Prosperity vs. People Prosperity: Welfare Considerations in the Geographic Redistribution of Economic Ac-tivity. In Real Estate Research Program, University of California at Los Angeles, Essay in Urban Land Economics in Honor of the Sixty Fifth Birthday of Leo Grebler; Real Estate Research Program: Los Angeles, CA, USA, 1966; pp. 273-283.

101. Nocera, F.; Giuffrida, S.; Trovato, M.R.; Gagliano, A. Energy and New Economic Approach for Nearly Zero Energy Hotels. Entropy 2019, 21, 639. [CrossRef]

102. OECD. Rural-Urban Partnerships-An Integrated Approach to Economic Development; OECD Publishing: Paris, France, 2013.

103. Peters, A.; Fisher, P. The Failures of Economic Development Incentives. J. Am. Plan. Assoc. 2004, 70, 27-37. [CrossRef]

104. Camagni, R. Principi di Economia Urbana e Territoriale; Carocci: Rome, Italy, 2011.

105. Giuffrida, S.; Gagliano, F.; Giannitrapani, E.; Marisca, C.; Napoli, G.; Trovato, M.R. Promoting Research and Landscape Experience in the Management of the Archaeological Networks. A Project-Valuation Experiment in Italy. Sustainability 2020, $12,4022$. [CrossRef]

106. Chimirri, R.; Meijer, M. Le Culture dell'Abitare Tradizionale per un Riuso dei Paesi della Calabria; FrancoAngeli: Milano, Italy, 2019.

107. Belsky, E.S.; DuBroff, N.; McCue, D.; Harris, C.; McCartney, S.; Molinsky, J. Advancing Inclusive and Sustainable Urban Development: Correcting Planning Failures and Connecting Communities to Capital; Joint Center for Housing Studies of Harvard University: Cambridge, MA, USA, 2013.

108. Nabil, N.A.; AbdEldayem, G.E. Influence of mixed land-use on realizing the social capital. HBRC J. 2015, 11, 285-298. [CrossRef]

109. Copeland, S.; Comes, T.; Bach, S.; Nagenborg, M.; Schulte, Y.; Doorn, N. Measuring social resilience: Trade-offs, challenges and opportunities for indicator models in transforming societies. Int. J. Disaster Risk Reduct. 2020, 51, 101799. [CrossRef]

110. Agenzia per la Coesione Territoriale. Strategia Nazionale Aree Interne (NSIA). 2011. Available online: https://www. agenziacoesione.gov.it/strategia-nazionale-aree-interne/ (accessed on 13 April 2021).

111. Giuffrida, S.; Trovato, M.R.; Strigari, A.; Napoli, G. "Houses for One Euro" and the Territory. Some Estimation Issues for the "Geographic Debt" Reduction. In New Metropolitan Perspectives. NMP 2020. Smart Innovation, Systems and Technologies; Bevilacqua, C., Calabrò, F., Della Spina, L., Eds.; Springer: Cham, Switzerland, 2021; Volume 178, pp. 1043-1052. [CrossRef]

112. Zamora, J.G. Diferencias sectoriales y regionales de la recesión económica motivadas por la pandemia de la COVID-19 en México y medidas de política pública para enfrentarla. Investig. Geogr. 2021, 105, e60391. [CrossRef]

113. Vecchio, G.; Tiznado-Aitken, I.; Steiniger, S. Vulnerable individuals and institutions: The double territorial burden of COVID-19 in Chile. Town Plan. Rev. 2021, 92, 271-277. [CrossRef]

114. Zizek, S. Virus. Catastrofe e Solidarietà; Ponte delle Grazie: Firenze, Italy, 2020.

115. Sébastien, L.; Bauler, T. Use and influence of composite indicators for sustainable development at the EU-level. Ecol. Indic. 2013, 35, 3-12. [CrossRef]

116. Ferguson, N.; Woods, L. Travel and mobility. In Dimensions of the Sustainable City, Future City; Jenks, M., Jones, C., Eds.; Springer: Dordrecht, The Netherlands, 2010; Volume 2, pp. 53-74.

117. Ministero dell'Ambiente e della Tutela del Territorio e del Mare. L'agenda 2030 e Gli Accordi Globali Sullo Sviluppo Sostenibile. Available online: www.minambiente.it/pagina/lagenda-2030-e-gli-accordi-globali-sullo-sviluppo-sostenibile (accessed on 10 October 2021).

118. Morrison, N.; Pearce, B. Developing indicators for evaluating the effectiveness of the UK land use planning system. Town Plan. Rev. 2000, 71, 191. [CrossRef]

119. Shiels, C.; Baker, D.; Barrow, S. "How accurately does regeneration target local need?" Targeting deprived communities in the UK. Int. J. Public Sect. Manag. 2013, 26, 203-215. [CrossRef]

120. de Groot, R. Function-analysis and valuation as a tool to assess land use conflicts in planning for sustainable, multi-functional landscapes. Landsc. Urban Plan. 2006, 75, 175-186. [CrossRef]

121. Della Spina, L.; Giorno, C.; Casmiro, R.G. An Integrated Decision Support System to Define the Best Scenario for the Adaptive Sustainable Re-Use of Cultural Heritage in Southern Italy. In New Metro-Politan Perspectives. NMP 2020. Smart Innovation, Systems and Technologies; Bevilacqua, C., Calabrò, F., Della Spina, L., Eds.; Springer: Cham, Switzerland, 2020; Volume 177, pp. 251-267. [CrossRef]

122. Agenzia per la Coesione Territoriale. La Finanza Territoriale 2021—Regioni e Territori, Dall'emergenza Sanitaria al PNRR. 2021. Available online: https://agenziacoesione.sebina.it/SebinaOpac/news/la-finanza-territoriale-2021-regioni-e-territoridallemergenza-sanitaria-al-pnrr/563 (accessed on 15 April 2021).

123. Boscarino, S.; Federico, A.; Giuffrida, S.; Prescia, R.; Rizzo, F. Petralia Soprana. Ipotesi di Restauro Urbano e Studi di Analisi Multi-criteriale; Medina: Palermo, Italy, 1994.

124. Bolasco, S. Analisi Multidimensionale dei Dati. Metodi, Strategie e Criteri D'Interpretazione, 6th ed.; Carocci: Rome, Italy, 2014. 
125. Giuffrida, S. City as Hope. Valuation Science and the Ethics of Capital. In Integrated Evaluation for the Management of Contemporary Cities, Green Energy and Technology; Mondini, G., Fattinnanzi, E., Oppio, A., Bottero, M., Stanghellini, S., Eds.; Springer: Cham, Switzerland, 2018; pp. 411-424. [CrossRef]

126. Giuffrida, S. A Fair City. Value, Time and the Cap Rate. In Integrated Evaluation for the Management of Contemporary Cities, Green Energy and Technology; Mondini, G., Fattinnanzi, E., Oppio, A., Bottero, M., Stanghellini, S., Eds.; Springer: Cham, Switzerland, 2018; pp. 425-439. [CrossRef]

127. Trovato, M.R.; Clienti, C.; Giuffrida, S. People and the City: Urban Fragility and the Real Estate-Scape in a Neighborhood of Catania, Italy. Sustainability 2020, 12, 5409. [CrossRef]

128. Glaeser, E.L.; Berry, C.R. The Divergence of Human Capital Levels Across Cities; NBER Working Paper \#11617; Annual Reviews Inc.: Palo Alto, CA, USA, 2005.

129. Gabrielli, L.; Giuffrida, S.; Trovato, M.R. Gaps and Overlaps of Urban Housing Sub-market: Hard Clustering and Fuzzy Clustering Approaches. In Appraisal from Theory to Practice; Green Energy and Technology; Stanghellini, S., Morano, P., Bottero, M., Oppio, A., Eds.; Springer Nature Switzerland AG: Cham, Switzerland, 2016; pp. 203-219. [CrossRef]

130. Gabrielli, L.; Giuffrida, S.; Trovato, M.R. From Surface to Core: A Multi-Layer Approach for the Real Estate Market Analysis of a Central Area in Catania. In Computational Science and Its Applications-ICCSA 2015, LCNS 9157; Gervasi, O., Murgante, B., Misra, S., Gavrilova, M.L., Rocha, A.M.A.C., Torre, C.M., Taniar, D., et al., Eds.; Springer Nature Switzerland AG: Cham, Switzerland, 2015; Volume III, pp. 284-300. [CrossRef]

131. Gabrielli, L.; Giuffrida, S.; Trovato, M.R. Functions and Perspectives of Public Real Estate in the Urban Policies: The Sustainable Development Plan of Syracuse. In Computational Science and Its Applications-ICCSA 2016, LNCS 9789; Gervdasi, O., Murgante, B., Misra, S., Rocha, A.M.A.C., Torre, C.M., Taniar, D., Apduhan, B.O., et al., Eds.; Springer Nature Switzerland AG: Cham, Switzerland, 2016; Volume IV, pp. 13-28. [CrossRef]

132. Napoli, G.; Giuffrida, S.; Trovato, M.R.; Valenti, A. Cap Rate as the Interpretative Variable of the Urban Real Estate Capital Asset: A Comparison of Different Sub-Market Definitions in Palermo, Italy. Buildings 2017, 7, 80. [CrossRef]

133. Valenti, A.; Giuffrida, S.; Linguanti, F. Decision Trees Analysis in a Low Tension Real Estate Market: The Case of Troina (Italy) Comput. Sci. Appl. 2015, 91, 237-252. [CrossRef]

134. Presidente della Repubblica. Disposizioni Urgenti per la Revisione della Spesa Pubblica con Invarianza dei Servizi ai Cittadini. Decreto-Legge del 6 Luglio 2012 n. 95 (Pubblicato in Gazzetta Ufficiale n. 156 del 6 Luglio 2012-Supplemento Ordinario). Available online: https://www.agenziaentrate.gov.it/portale/documents/20143/261699/Dl+06072012+n95_DL_95_6luglio2 012.pdf/dd12dfa9-f6ec-2242-3ab6-8db8d3f8738e?version=1.0 (accessed on 1 August 2021).

135. Bilsborrow, R.; Okoth-Ogendo, H.W.O. Population-driven changes in land-use in developing countries. Ambio 1992, $21,37-45$.

136. Trovato, M.R. Human Capital Approach in the Economic Assessment of Interventions for the Reduction of Seismic Vulnerability in Historic Centres. Sustainability 2020, 12, 8059. [CrossRef]

137. Reckien, D. What is in an index? Construction method, data metric, and weighting scheme determine the outcome of composite social vulnerability indices in New York City. Reg. Environ. Chang. 2018, 18, 1439-1451. [CrossRef]

138. D'Agostini, F. Introduzione alla Verità; Bollati Boringhieri: Torino, Italy, 2011.

139. Khan, S. Vulnerability assessments and their planning implications: A case study of the Hutt Valley, New Zealand. Nat. Hazards 2012, 64, 1587-1607. [CrossRef]

140. Keeney, R.L.; Raiffa, H.; Meyer, R.F. Decisions with Multiple Objectives: Preferences and Value Trade-Offs; Cambridge University Press: Cambridge, UK, 1993.

141. Von Winterfeldt, D.; Edwards, W. Decision Analysis and Behavioral Research; Cambridge University Press: Cambridge, UK, 1986.

142. Montibeller, G.; Yoshizaki, H. A Framework for Locating Logistic Facilities with Multi-Criteria Decision Analysis. Lect. Notes Comput. Sci. 2011, 6576, 505-519. [CrossRef]

143. Herwijnen, M.V. Spatial Decision Support for Environmental Management; Vrije Universiteit: Amsterdam, The Netherlands, 1999.

144. Beinat, E. Value Functions for Environmental Management; Kluwer Academic Publishers: Dordrecht, The Netherlands, 1997.

145. Roy, B.; Mousseau, V. A theoretical framework for analysing the notion of relative importance of criteria. J. Multi. Crit. Decis. Anal. 1996, 5, 145-159. [CrossRef]

146. Choo, E.U.; Schoner, B.; Wedley, W.C. Interpretation of criteria weights in multicriteria decision making. Comput. Ind. Eng. 1999, 37, 527-541. [CrossRef]

147. Poyhonen, M.; Hamalainen, R.P. On the convergence of multi-attribute weighting methods. Eur. J. Oper. Res. 2001, 129, 569-585. [CrossRef]

148. Carpenter, J. Addressing Europe's Urban Challenges: Lessons from the EU URBAN Community Initiative. Urban Stud. 2006, 43, 2145-2162. [CrossRef]

149. Khare, A.T. Putting People Back into Place-Based Public Policies. J. Urban Aff. 2015, 37, 47-52. [CrossRef]

150. Arribas-Bel, D.; Kourtit, K.; Nijkamp, P. Benchmarking of world cities through Self-Organizing Maps. Cities 2013, 31, 248-257. [CrossRef]

151. Luque-Martínez, T.; Muñoz-Leiva, F. City benchmarking: A methodological proposal referring specifically to Granada. Cities 2005, 22, 411-423. [CrossRef]

152. Dallara, A.; Rizzi, P. Geographic Map of Sustainability in Italian Local Systems. Reg. Stud. 2012, 46, 321-337. [CrossRef]

153. Hagelman, R. Visualizing Demographic Trajectories with Self-Organizing Maps. GeoInformatica 2005, 9, 159-179. [CrossRef] 
154. Vallés-Planells, M.; Galiana, F.; Van Eetvelde, V. A Classification of Landscape Services to Support Local Landscape Planning. Ecol. Soc. 2014, 19. [CrossRef]

155. Giuffrida, S.; Ventura, V.; Trovato, M.R.; Napoli, G. Axiology of the historic city and the cap rate the case of the old town of Ragusa superior. Valori Valutazioni 2017, 18, 41-55.

156. Giuffrida, S.; Carocci, C.; Circo, C.; Giuffre, M.; Rosa Trovato, M.; Ventura, V. Axiological strategies in the old towns seismic vulnerability mitigation planning. Valori Valutazioni 2020, 25, 99-106.

157. Giuffrida, S.; Trovato, M.R.; Circo, C.; Ventura, V.; Giuffrè, M.; Macca, V. Seismic Vulnerability and Old Towns. A Cost-Based Programming Model. Geosciences 2019, 9, 427. [CrossRef]

158. Dempsey, N.; Brown, C.; Raman, S.; Porta, S.; Jenks, M.; Jones, C.; Bramley, G. Elements of urban form. In Dimensions of the Sustainable City. Future City; Jenks, M., Jones, C., Eds.; Springer: Dordrecht, The Netherlands, 2010; Volume 2, pp. $21-51$.

159. Jabareen, Y.R. Sustainable urban forms: Their typologies, models, and concepts. Plan. Educ. Res. 2006, 26, 38-52. [CrossRef]

160. Jenks, M.; Jones, C. Issues and concepts. In Dimensions of the Sustainable City. Future City; Jenks, M., Jones, C., Eds.; Springer: Dordrecht, The Netherlands, 2010; Volume 2, pp. 1-19.

161. Lynch, K. A Theory of Good City Form; MIT Press: Cambridge, MA, USA, 1981; pp. 111-120.

162. Bolton, R. 'Place Prosperity vs. People Prosperity' Revisited: An Old Issue with a New Angle. Urban Stud. 1992, 29, 185-203. [CrossRef]

163. Bonomi, A.; Masiero, R. Dalla Smart City alla Smart Land; Marsilio Editori: Venezia, Italy, 2014.

164. Croci, E.; L'agenda Urbana per lo Sviluppo Sostenibile. Presentazione Incontro OCSE-ComPA, Trasformazioni Ambientali e Paesaggi Locali, 31 Ottobre 2018, Udine. 2018. Available online: https:/ / compa.fvg.it/I-nostri-progetti/Comprendere-letendenze-globali-per-innovare-gliEE.LL/Trasformazioni-ambientali-e-paesaggi-locali (accessed on 10 October 2021).

165. Giuffrida, S.; Ventura, V.; Nocera, F.; Trovato, M.R.; Gagliano, F. Technological, Axiological and Praxeological Coordination in the Energy-Environmental Equalization of the Strategic Old Town Renovation Programs. In Values and Functions for Future Cities; Mondini, G., Oppio, A., Stanghellini, S., Bottero, M., Abastante, F., Eds.; Part of Green Energy and Technology; Springer Nature Switzerland AG: Cham, Switzerland, 2019; pp. 425-446. [CrossRef]

166. Wenger, E. Communities of Practice: Learning, Meaning and Identity; World Commission on Environment and Development (WCED); Cambridge University Press: New York, NY, USA, 1987.

167. OECD. Culture and Local Development; OECD Publishing: Paris, France, 2005. [CrossRef]

168. Bettencourt, L.M.A. The Origins of Scaling in Cities. Science 2013, 340, 1438-1441. [CrossRef]

169. Batty, M. The Size, Scale, and Shape of Cities. Science 2008, 319, 769-771. [CrossRef]

170. Giannelli, A.; Giuffrida, S.; Trovato, M.R. Madrid Rio Park. Symbolic Values and Contingent Valuation, Valori e valutazioni. E-Flow Tipogr. Genio Civ. 2018, 21, 75-85.

171. UN-Habitat. International Guidelines on Urban and Territorial Plan. Handbook. HS/052/18E. 2018. Available online: https://unhabi-tat.org/sites /default/files/documents/2019-05/international_guidelines_on_urban_and_territorial_ planning_-_handbook_.pdf (accessed on 10 October 2021).

172. UN-Habitat. Implementing the New Urban Agenda by Strengthening Urban-Rural Linkages. HS/035/17E. 2017. Available online: https:/ / urban-gate-way.org/system/files/documents/urbangateway/urban_rural_linkages_for_implementing_the_ new_urban_agenda_low_resolution.pdf (accessed on 10 October 2021).

173. Del Espino Hidalgo, B. Mid-Sized Cities in the centre of Andalusia. An approach to an urban-territorial phenomeno. Rev. De Estud. Reg. 2017, 108, 165-191.

174. Adam, B. Medium-sized cities in urban regions. Eur. Plan. Stud. 2006, 14, 547-555. [CrossRef]

175. Boix, D.R.; Trullén, T.J. Policentrism and space structure: A critical review from the perspective of research programs. Archit. City Environ. 2012, 18, 27-54. Available online: http://www-cpsv.upc.es/ace/Articles_n18/articles_PDF/ACE_18_SE_20.pdf (accessed on 2 April 2021).

176. Giuffrida, S.; Gagliano, F.; Nocera, F.; Trovato, M.R. Landscape Assessment and Economic Accounting in Wind Farm Programming: Two Cases in Sicily. Land 2018, 7, 120. [CrossRef]

177. Camagni, R.; Capello, R.; Caragliu, A. Equilibrium vs. optimal city size: Evidence from Italian cities. Int. J. Glob. Environ. Issues 2014, 13, 170. [CrossRef]

178. Matthews, R.; Selman, P. Landscape as a Focus for Integrating Human and Environmental Processes. J. Agric. Econ. 2006, 57, 199-212. [CrossRef]

179. Xinyue, Y.; Xingian, L. (Eds.) Cities as Spatial and Social Networks; Springer Nature: Cham, Switzerland, 2019.

180. Pflieger, G.; Rozenblat, C. Introduction. Urban Networks and Network Theory: The City as the Connector of Multiple Net-works. Urban Stud. 2010, 47, 2723-2735. Available online: https://www.jstor.org/stable/43079955 (accessed on 22 September 2021). [CrossRef]

181. Napoli, G.; Giuffrida, S.; Trovato, M.R. A Paradigm Interpreting the City and the Analytic Network Process for the Management of Urban Transformations. In Proceedings of the Smart Innovation, Systems and Technologies, 3rd International New Metropolitan Perspectives. Local Knowledge and Innovation Dynamics towards Territory Attractiveness through the Implementation of Hori-zon/Europe2020/Agenda2030, Reggio Calabria, Italy, 22-25 May 2018; Bevilacqua, C., Calabrò, F., Della Spina, L., Eds.; Springer Science and Business Media Deutschland GmbH: Cham, Switzerland, 2019; Volume 101, pp. 672-680. [CrossRef] 
182. Mazziotta, M.; Pareto, A.A. Composite index for measuring italian regions' development over time. Riv. Ital. Econ. Demogr. 2014, $68,127-134$.

183. Pawlowsky-Glahn, V.; Buccianti, A. Compositional Data Analysis: Theory and Applications; John Wiley \& Sons: Chichester, UK, 2011.

184. Pawlowsky-Glahn, V.; Egozcue, J.J. Geometric approach to statistical analysis in the symplex. Stoch. Environ. Res. Risk Assess. 2001, 15, 384-398. [CrossRef]

185. Pawlowsky-Glahn, V.; Egozcue, J.J.; Tolosana-Delgado, R. Modelling and Analysis of Compositional Data; Wiley: Hoboken, NJ, USA, 2015.

186. Giuffrida, S.; Casamassima, G.; Trovato, M.R. Le norme EMAS-ISO nella valutazione della qualità del servizio idrico integrato. Aestimum 2017, 70, 109-134. [CrossRef]

187. Ramsay, J.; Silvermann, B. Functional Data Analysis. Springer Series in Statistics. Biom. J. 1998, 40, 56. [CrossRef]

188. Pires, S.M.; Fidélis, T.; Ramos, T. Measuring and comparing local sustainable development through common indicators: Constraints and achievements in practice. Cities 2014, 39, 1-9. [CrossRef]

189. Van den Boogaart, K.G.; Tolosana-Delgado, R.; Bren, M. Compositions: Compositional Data Analysis. R Package Version 1.40-2. 2018. Available online: https:/ /CRAN.R-project.org/package $=$ compositions (accessed on 1 August 2021).

190. Anselin, L. Local indicators of spatial association-LISA. Geogr. Anal. 1995, 27, 93-115. [CrossRef]

191. Anselin, L.; Syabri, I.; Kho, Y. GeoDa: An Introduction to Spatial Data Analysis. Geogr. Anal. 2005, 38, 5-22. [CrossRef]

192. Greenbaum, R.; Bondonio, D. Losing Focus: A Comparative Evaluation of Spatially Targeted Economic Revitalization Programmes in the US and the EU. Reg. Stud. 2004, 38, 319-334. [CrossRef]

193. Cerreta, M.; Panaro, S.; Poli, G. A Spatial Decision Support System for Multifunctional Landscape Assessment: A Transformative Resilience Perspective for Vulnerable Inland Areas. Sustainability 2021, 13, 2748. [CrossRef]

194. Giuffrida, S.; Trovato, M.R.; Falzone, M. The Information Value for Territorial and Economic Sustainability in the Enhancement of the Water Management Process. Comput. Sci. Appl. 2017, 10406, 575-590. [CrossRef]

195. Cerreta, M.; Panaro, S. From Perceived Values to Shared Values: A Multi-Stakeholder Spatial Decision Analysis (M-SSDA) for Resilient Landscapes. Sustainability 2017, 9, 1113. [CrossRef]

196. Chen, Y.; Yu, J.; Khan, S. Spatial sensitivity analysis of multi-criteria weights in GIS-based land suitability evaluation. Environ. Model. Softw. 2010, 25, 1582-1591. [CrossRef]

197. Bailey, K.; Grossardt, T. Toward structured public involvement: Justice, geography and collaborative geospatial/geovisual de-cision support systems. Ann. Assoc. Am. Geogr. 2010, 100, 57-86. [CrossRef]

198. Partridge, M.D.; Rickman, D.; Olfert, M.R.; Tan, Y. When Spatial Equilibrium Fails: Is Place-Based Policy Second Best? Reg. Stud. 2013, 49, 1303-1325. [CrossRef]

199. Spielman, S.E.; Thill, J.-C. Social area analysis, data mining, and GIS. Comput. Environ. Urban Syst. 2008, 32, 110-122. [CrossRef]

200. Giuffrida, S.; Gagliano, F.; Trovato, M.R. Land as Information. A Multidimensional Valuation Approach for Slow Mobility Planning. In Proceedings of the 7th International Conference on Information and Communication Technologies in Agriculture, Food and Environment (HAICTA 2015), Kavala, Greece, 17-20 September 2015; Andreopoulou, Z., Bochtis, D., Eds.; CEUR Workshop Proceedings: Aachen, Germany, 2015; pp. 879-891.

201. Malczewski, J. GIS-based multicriteria decision analysis: A survey of the literature. Int. J. Geogr. Inf. Sci. 2006, 20, 703-726. [CrossRef]

202. Berkes, F. Understanding uncertainty and reducing vulnerability: Lessons from resilience thinking. Nat. Hazards 2007, 41, 283-295. [CrossRef]

203. Graziano, P.; Rizzi, P. Resilience and vulnerability in European regions. Sci. Reg. 2020, 19, 91-118. [CrossRef]

204. Balletto, G.; Borruso, G.; Murgante, B.; Milesi, A.; Ladu, M. Resistance and Resilience. A Methodological Approach for Cities and Territories in Italy. In Proceedings of the International Conference on Computational Science and Its Applications, Cagliari, Italy, 13-16 September 2021; Springer: Cham, Switzerland, 2021; pp. 218-229. [CrossRef]

205. Prigogine, I.; Nicolis, G. Self-Organization in Non-Equilibrium Systems; Wiley: Hoboken, NJ, USA, 1977.

206. Rizzo, F. Value and Evaluations. The Science of Economics or the Economics of Science; Franco Angeli: Milan, Italy, 1999. 